\title{
HELPPOA VAI VAATIVAMPAA SELKOKIELTÄ - SELKOKIELEN MITTAAMINEN JA VAIKEUSTASOT
}

\section{Leealaura Leskelä, Kehitysvammaliitto / Selkokeskus}

\begin{abstract}
Selkokielen tarve on viime vuosina kasvanut Suomessa. Samalla on herännyt tarve määritellä aiempaa tarkemmin selkokielen vaikeustasoja ja eroa muihin kielimuotoihin. Miten helppoa tai vaikeaa selkokieli voi olla erilaisille lukijoille ja eri teksteissä, ja voiko tekstien selkokielisyyttä arvioida?

Tässä artikkelissa pohditaan, millaisia vaikeustasojen määritelmiä selkokielelle voitaisiin antaa. Selkokieltä on Suomessa aina tuotettu monella vaikeustasolla, mutta näitä tasoja ei ole aiemmin määritelty. Niinpä selkoaineistojen käyttäjät eivät ole voineet tietää, millaista vaikeustasoa jokin selkokielinen aineisto on. Käytännössä erilaisille vaikeustasoille on Suomessa tarvetta, sillä osalla selkokielen kohderyhmistä kielen ja lukemisen vaikeudet ovat erittäin suuria ja osalla taas melko pieniä. Artikkelissa hahmotellaan alustavia kriteerejä kolmelle selkokielen vaikeustasolle, helpolle selkokielelle, perusselkokielelle sekä vaativalle selkokielelle.

Selkokielen tarpeen kasvaessa selkotekstien arviointiin ja määrittelemiseen tarvitaan myös uusia työvälineitä. Selkokeskuksessa on viime vuosina kehitetty selkokielen mittaria, jonka avulla on tarkoitus arvioida, onko jokin teksti perusselkokieltä vai ei. Mittari sisältää toistaiseksi tarkimman kuvauksen selkosuomen tekstuaalisista, sanastollisista ja rakenteellisista piirteistä, mutta soveltuuko se tekstin selkokielisyyden mittaamiseen? Tätä kysymystä lähestytään artikkelissa mittarin kehittämistyön ja testaustulosten valossa.
\end{abstract}

Avainsanat: selkokieli, selkotekstien arviointi, selkokielen mittari, selkokielen vaikeustasot

\section{JOHDANTO}

Viime vuosina selkokielen vaikeustasojen tarkka ja suunnitelmallinen määritteleminen on tullut Suomessa ajankohtaiseksi. Nykyisen selkokielen määritelmän mukaan selkokieli on suomen kielen muoto, joka on sanastoltaan,

Kirjoittajan yhteystiedot:

Leealaura Leskelä

leealaura.leskela@helsinki.fi rakenteiltaan ja sisällöltään yleiskieltä ymmärrettävämpää ja luettavampaa (mm. KulkkiNieminen, 2010, s. 27-29; Leskelä, 2019, s. 93-96; Leskelä \& Virtanen, 2006; Virtanen, 2009, s. 17; Uotila, 2019). Eri vaikeustasoja määritelmässä ei mainita, mutta käytännössä selkokieliset materiaalit ovat olleet vaikeustasoltaan hyvin vaihtelevia (Virtanen, 2009, s. 66-67). Myös selkotunnus on Suomessa myönnetty vaikeustasoltaan monenlaisille julkaisuille varsin yksinkertaisesta kielellisestä ilmaisusta melko vaativaan. Sopivan vaikeus- 
tason ratkaiseminen on siten oikeastaan jätetty selkokirjoittajille - ja sopivan luettavan löytäminen selkolukijoille.

Selkokielen vaikeustasoihin liittyviä kommentteja esitetään ajoittain myös julkisuudessa. Toisinaan selkoaineistoja kritisoidaan liian vaikeiksi, toisinaan taas liian helpoiksi (Virtanen, 2009, s. 118). Esimerkiksi Selkosanomien lukijakyselyssä 2016 kymmenen prosenttia lukijoista piti lehden käyttämää kieltä liian vaikeana ja kuusi prosenttia taas liian helppona (Juusola, 2016, s. 46). Joskus selkokielestä halutaan karsia pois esimerkiksi taivutuspäätteitä tai tiettyä sanastoa. Joskus taas paheksutaan kankeaa kieltä, jota syntyy liiallisen yksinkertaistamisen vuoksi (Virtanen, 2009, s. 112-118). Kansainvälisissä katsauksissa liian helpon selkokielen on myös pelätty leimaavan käyttäjiään, aiheuttavan syrjintää, estävän oppimista, uhkaavan yleiskielen asemaa tai vieraannuttavan hyvästä kielenkäytöstä (Bock, 2015; Bredel \& Maaß, 2016a, s. 45-56).

Kiinnostus selkokieltä kohtaan on lisääntynyt erityisesti Keski-Euroopan saksankielisissä maissa 2010-luvulla. Selkosaksaksi (Leichte Sprache) määritellään kaikkein yksinkertaisin kielen muoto, jolle on annettu tarkat ja tiukat säännöt (Bredel \& Maaß, 2016a, s. 58-59). Näiden sääntöjen mukaan monet Suomen selkojulkaisut eivät olisi selkokieltä lainkaan. Kaikki muu yleiskieltä helpompi saksa on $y k$ sinkertaista kieltä (Einfache Sprache) ${ }^{1}$, jolle ei ole tiukkoja sääntöjä, vaan ennemmin suosituksia (Bredel \& Maaß, 2016b, s. 186-196). Saksan määritelmä asettaa myös selkosuomen määrittelemiselle uudenlaisen haasteen.

Tämän artikkelin tavoitteena on hahmotella selkosuomen kolmen eri vaikeustason kielellisiä kriteerejä. Tasojen määrittelyn

1 Englanniksi selkokieleen viitataan pääosin käsitteellä Easy to Read, toisinaan myös Easy English tai Easy Language. Plain Language puolestaan on käsite, jolla viitataan enimmäkseen selkeään yleiskieleen. pohjana on syksyllä 2018 julkaistu selkokielen mittari ${ }^{2}$, jonka tarkastelu selkokielisyyden arvioinnin työkaluna on tämän artikkelin toinen pääaihe. Mittariin on koottu laajin ja tarkin selkokielen kriteeristö Suomessa viime vuosikymmenien aikana kehitetystä selkokielen ohjeistuksesta (esim. Leskelä, 2019; Leskelä \& Kulkki-Nieminen, 2015; Sainio 2006; Sainio \& Rajala, 2002; Virtanen, 2009). Tutkimusta selkosuomen vaikeustasoista ja selkotekstien arvioinnista on vielä niukasti, joten tässä artikkelissa esitetyt havainnot perustuvat pitkälti käytännön kehittämistyöhön. Toivon näiden havaintojen johtavan jatkossa myös selkokielen vaikeustasojen ja mittarin tutkimukseen.

Artikkelin alussa luon katsauksen selkokielen teorian muodostumisen kannalta olennaisiin kansainvälisiin ohjeistuksiin sekä niiden taustalla vaikuttaneisiin teksti- ja vastaanottajalähtöisiin näkökulmiin. Tarkastelen myös saavutettavuuden käsitettä, joka on viime vuosina yhä laajemmin määritellyt selkokielen kehittämisen suuntaa. Sen jälkeen hahmottelen yhden esimerkkitekstin valossa, millaisia kielellisiä kriteerejä selkokielen eri vaikeustasoille voidaan antaa, jos lähtökohtana on selkokielen mittarin kuvaama perusselkokielen taso. Lopuksi kuvaan selkokielen mittarin kehittämisprosessia sekä arvioin, toimiiko mittari selkokielisten tekstien arvioinnin työkaluna.

\subsection{Kansainväliset selkokielen ohjeet}

Selkokielen kriteerejä on määritelty Suomessa 1980-luvulta lähtien, aluksi pitkälti kansainvälisiä ohjeistuksia soveltamalla, sittemmin enemmän suomen kielen lähtökohdista (Leskelä, 2019, s. 110-111). Suomen varhaisiin selko-ohjeisiin vaikutti kaksi

\footnotetext{
2 Selkokielen mittari: https://selkokeskus.fi/selkokieli/selkokielen-mittari/. Tämän artikkelin liitteenä tiivistelmä mittarista.
} 
kansainvälistä ohjeistusta: kirjastojärjestö IFLA:n selko-ohjeistus (IFLA, 1996; IFLA, 2010) sekä kehitysvammaisten ihmisten ja heidän omaistensa kattojärjestön Inclusion Europen ohjeistus (ILSHM, 1998; IE, 2009). 1990-luvulla julkaistut ohjeistukset sisälsivät keskenään melko yhtenevät selkokielen kriteeristöt. Kummatkin ohjeistukset uudistettiin vuosina 2009 ja 2010, jolloin ne muuttuivat varsin eri suuntiin. IFLA:n ohjeistus muutettiin aiempaa joustavammaksi, sillä liian tiukkojen ja yksityiskohtaisten sääntöjen ajateltiin kahlitsevan selkokielen ilmaisukeinoja, kehittämistä ja sovellettavuutta. Inclusion Europen ohjeistusta taas tiukennettiin, sillä aikeisempi ohjeistus koettiin liian sallivaksi ja joustavaksi. Uudistuksessa erityinen painoarvo annettiinkin tekstejä tarkastaville kehitysvammaisille henkilöille, jotka viime kädessä päättivät, mitkä ohjeista hyväksytään ja mitkä ei (Leskelä, 2019, s. 110-112).

Suomen kannalta kansainvälisten ohjeistusten ongelma on se, että ne on laadittu indoeurooppalaisten kielten lähtökohdista ${ }^{3}$. Suomen kaltaisessa agglutinoivassa kielessä ei riitä, että kehotetaan käyttämään yksinkertaisia sanoja ja lyhyitä lauseita, vaan tarvitaan tarkennuksia, millainen sanataivutus tai lauserakenne on helppo tai vaikea. Viime vuosikymmeninä Suomessa onkin pohdittu suomen kielen kannalta relevantteja selkokielen periaatteita. Muun muassa Selkokeskus on julkaissut vuosien varrella useita oppaita, joissa on arvioitu kansainvälisten ohjeiden soveltuvuutta selkosuomeen (esim. Leskelä, 2019; Leskelä \& Virtanen, 2006; Leskelä \& Kulkki-Nieminen, 2015; Sainio \& Rajala, 2002; Virtanen, 2009).

Vaikka selkosuomi tarvitsee omia kielellisiä periaatteita, myös kansainvälisten ohjeiden

\footnotetext{
3 Inclusion Europen selko-ohjeiden uudistuksessa oli mukana suomalaisia toimijoita, mutta ohjeet ovat kielestä riippumattomia eivätkä sisällä suomen kieleen liittyviä erityispiirteitä.
}

kehittymistä on syytä seurata Suomessa tarkasti. Tällä hetkellä kiinnostavia ovat etenkin saksankielisellä alueella julkaistut selkokielen säännöt. Näitä ovat muun muassa Netzwerk Leichte Sprache -verkoston selko-ohjeet (NLS, 2013) sekä Hildesheimin yliopiston selkokielen tutkimuskeskuksen julkaisut (Bredel \& Maaß, 2016a; 2016b; Maaß, 2015; Maaß \& Rink, 2019). Saksan selkosääntöjen peilaaminen selkosuomen ohjeisiin on kiinnostavaa erityisesti selkokielen vaikeustasojen näkökulmasta, sillä Saksan säännöissä selkokieleksi määritellään vain kaikkein helpoin kielimuoto (Bredel \& Maaß, 2016a, s. 110-116). Tiukat, ehdottomat ja yleiskielestä poikkeavat säännöt on Pohjoismaissa pääosin koettu vieraiksi, mutta juuri ehdottomuutensa vuoksi Saksan sääntöjä voi pitää hyvänä vertailukohtana helpolle selkokielelle.

Sekä Suomessa että kansainvälisesti selkoohjeistukset ovat omaksuneet vaikutteita teoreettisista lähtökohdista, jotka voi karkeasti jakaa tekstilähtöisiin ja vastaanottajalähtöisiin. Kummallakin lähtökohdalla on selkokielen teorialle paljon annettavaa, mutta niihin liittyy myös rajoituksia, jotka on hyvä tiedostaa.

\subsection{Tekstin ymmärrettävyys lähtökohtana}

Tekstin ymmärrettävyyden teorioita on kehitetty etenkin kielitieteellisissä ja psykologisissa tutkimustraditioissa, joissa on tarkasteltu tekstin ymmärrettävyyttä (engl. understandability) ja luettavuutta (engl. readability) lisääviä tai vähentäviä tekijöitä (ks. esim. Bredel \& Maaß, 2016a, s. 61-62; Bock, Lange \& Fix 2017; Christmann, 2017; Leskelä, 2019, s. 86-87). Suomen varhaisiin selkokielen teorioihin nämä näkökulmat vaikuttivat epäsuorasti muun muassa viestinnäntutkija Osmo A. Wiion tekstien ymmärrettävyyttä koskevien käsitysten kautta (Uotila, 2019; Wiio, 1974). 
Perinteiset luettavuuden teoriat tarkastelevat tekstin helppolukuisuutta yleensä sen pintatason ominaisuuksien pohjalta (esim. sanojen ja lauseiden pituus). Teksti on siis helppolukuista, jos siinä on keskimäärin lyhyistä sanoista koostuvia lyhyitä lauseita ${ }^{4}$. Tältä pohjalta on kehitetty lukuisia mekaanisia luettavuuskaavoja, jotka pisteyttävät tekstejä niiden vaikeustason mukaan. Esimerkiksi LIX Readability Formulan (lix) mukaan teksti on hyvin helppoa kieltä, jos sen pistemäärä on 20-25, ja hyvin vaikeaa, jos pistemäärä on yli 60 (readabilityformulas.com) (ks. myös Uotila, 2019). Luettavuusindeksien ongelma on, että ne määrittelevät myös lyhyen mutta täysin järjettömän lauseen hyvin luettavaksi. Ne eivät myöskään osaa arvioida, milloin lauseessa on liikaa informaatiota tai tekstin kokonaisrakenne heikentää luettavuutta (Virtaluoto \& Väyrynen, 2000). Siksi luettavuusindeksit eivät voi selittää kuin osan tekstin luettavuuteen vaikuttavista seikoista. Koska ne eivät hahmota sanojen merkityksiä eivätkä ymmärrä lausetta pidempiä kokonaisuuksia, selkokielen kriteerit eivät voi perustua vain niihin (Leskelä, 2019, s. 88).

Tekstilähtöistä näkökulmaa on hyödynnetty myös tuoreessa selkokielen tutkimuksessa, mutta tarkastelun painopiste on siirtynyt kvalitatiiviseen tekstintutkimukseen. Esimerkiksi Kulkki-Nieminen (2010) vertaili väitöstutkimuksessaan selko- ja yleiskielisiä uutisia systeemis-funktionaalisen kieliteorian ja genrepedagogiikan näkökulmasta. Vertailevan tutkimusasetelman kautta voidaan täsmentää selkokielen periaatteita ja tarkastella kielimuotojen eroja ja määrittelyä. Tämän lähestymistavan ansiosta selkokielen teoriassa on myös kiinnitetty entistä enemmän huomiota siihen, miten tekstilajit vaikuttavat sel-

4 Luettavuuteen vaikuttavat luettavuustutkimusten mukaan myös tekstin visuaaliset piirteet, esimerkiksi kapea palsta tai helposti hahmotettava kirjain. Myös näillä on ollut vaikutusta selkokielen ohjeistuksiin. kokielen kriteeristöön (Kulkki-Nieminen \& Leskelä, 2012; Leskelä \& Kulkki-Nieminen, 2015).

\subsection{Vastaanottajan lukuprosessi lähtökohtana}

Toista selkokieleen vaikuttanutta tutkimussuuntaa voi kutsua vastaanottajalähtöiseksi. Lähtökohtana ovat tietynlaisen lukijan kielelliset kyvyt ja kognitiivinen kapasiteetti, jotka luonnollisesti ovat yksilöllisiä ja vaihtelevia. Kyky ymmärtää ja tulkita tekstiä riippuu monella tapaa vastaanottajasta - esimerkiksi hänen muistikapasiteetistaan, keskittymiskyvystään, ongelmanratkaisutaidoistaan sekä kiinnostuksestaan tekstiä kohtaan (Leskelä, 2019, s. 89-90; vrt. myös Christmann, 2017). Tämän näkökulman kautta avautuu laaja kirjo erilaisia tutkimustraditioita ja teorioita, jopa tieteenaloja, jotka voivat tarkentaa selkokielen kriteerejä. Esimerkiksi kognitiivinen psykologia, kielitiede, neurotieteet, vammaistutkimus, lääketiede, gerontologia sekä lukemisen ja oppimisen teoriat tarjoavat kaikki relevantteja teoreettisia lähtökohtia selkokielen tutkimukselle.

Suomen selko-ohjeissa kehotetaan pohtimaan tekstiä lukijan näkökulmasta. Kirjoittajan toivotaan esimerkiksi järjestävän lukijatapaamisia saadakseen palautetta tekstistä ja mahdollisuuden testata sen ymmärrettävyyttä (Leskelä \& Kulkki-Nieminen, 2015, s. 35). Myös Selkokeskus järjestää säännöllisesti lukijatestauksia eri kohderyhmien parissa sekä kehittää testausmalleja (Leskelä, 2011).

Monissa kansainvälisissä selko-ohjeissa lukijan ratkaiseva asema korostuu vielä enemmän kuin Suomessa (ks. esim. Candussi \& Frölich, 2015; NLS, 2013). Esimerkiksi saksankielisen Netzwerk Leichte Sprache -verkoston selkosääntöjen mukaan selkotekstiksi ei voi nimittää mitään, mitä kohderyhmät, erityisesti kehitysvammaiset henkilöt, eivät ole 
testanneet ja hyväksyneet. Verkoston ohjeissa asia sanotaan selkokielellä näin: Menschen mit Lern-Schwierigkeiten sind Fach-Leute. Das sind die Prüfer und Prüferinnen für Leichte Sprache. Nur sie können Ihnen wirklich sagen: Das kann ich gut verstehen. Verstehen die Prüfer und Prüferinnen den Text? Dann ist der Text gut. Verstehen die Prüfer und Prüferinnen etwas nicht? Dann ist der Text nicht gut. (NLS, 2013) [Suom. Kehitysvammaiset ihmiset ovat ammattilaisia. He ovat selkokielen tarkistajia. Vain he voivat todella sanoa Teille: Tämän ymmärrän hyvin. Ymmärtävätkö testaajat tekstiä? Silloin teksti on hyvä. Eivätkö testaajat ymmärrä jotakin? Silloin teksti ei ole hyvä.]

Suomessa tekstin testaus kohderyhmällä ei ole selkokielisyyden määrittelyn ehto, vaikka testausta onkin selkokirjoittajille suositeltu (Leskelä, 2011, s.18; Leskelä, 2019, s. 116; Leskelä \& Kulkki-Nieminen, 2015, s. 52-54; Virtanen, 2009, s. 104). Kohderyhmätestauksissa on otettava huomioon muutamia rajoituksia. Testauksissa voidaan harvoin käyttää niin suuria testaajajoukkoja, että yksittäisen lukijan mielipide ei vaikuttaisi tulokseen. Kielen ja lukemisen kyvyt vaihtelevat yksilöllisesti, samoin testaajan ennakkotiedot aiheesta sekä kiinnostus siihen. Selkokielen kohderyhmät myös eroavat toisistaan monin tavoin, joten on todennäköistä, että he kokevat eri asiat tekstissä vaikeiksi tai helpoiksi. Lisäksi osalla selkokielen kohderyhmistä on havaittu taipumusta niin sanottuun myöntyvyyteen, mikä voi heikentää saatujen testaustulosten luotettavuutta (Leskelä, 2019, s. 228-230; Leskelä, 2012; Nummelin, Matikka \& Vesala, 2000; Virtanen, 2009, s. 23-24, 104-105).

Edellä kuvatuista puutteista huolimatta lukijatestauksille on kuitenkin myös tarvetta. Pienikin testaajajoukko voi antaa kirjoittajalle arvokasta tietoa tekstin ymmärrettävyydestä ja auttaa sen muokkaamisessa, vaikka tieto ei riitäkään tekstin selkokielisyyden määrittelemiseen. Lukijatestauksien tulokset voi- vat vahvistaa tai osoittaa vääriksi käsityksiä siitä, mitkä asiat yhdistävät tai erottavat eri kohderyhmiä. Yksi tällainen havainto on, että hitaasti etenevät kielenoppijat, joilla on oman äidinkielensä luku- ja kirjoitustaidossa puutteita, näyttävät kielen oppimisen alkeistasolla hyötyvän suunnilleen samoista selkokielen keinoista kuin heikoimmin lukevat kehitysvammaiset henkilöt (Leskelä \& KulkkiNieminen, 2015, s. 30-32). Lukijatestauksia tarvitaan myös selkokielen vaikeustasojen määrittelemiseen, jotta saadaan kattava kuva siitä, millaisia tekstejä milläkin kielenosaamisen tasolla tarvitaan.

Tekstilähtöisyys ei sulje pois lukijan näkökulmaa, vaan parhaimmillaan ne täydentävät toisiaan. Tuoreessa selkokielen tutkimuksessa kiinnitetäänkin huomiota kumpaankin (vrt. esim. Bock, Lange \& Fix, 2017; Candussi \& Fröhlich, 2015). Paras tulos saadaan yhdistämällä tekstianalyysiin esimerkiksi keskustelun ja haastattelun avulla saatua tietoa lukijan kokemuksista (Heikkinen, 2012). Heikkisen (mt.) mukaan tällaista monimetodista lähestymistapaa, joka yhdistää tekstilähtöistä ymmärrettävyysanalyysia ja "tekstinulkoista todellisuutta", kuvaa parhaiten saavutettavuuden käsite.

\subsection{Saavutettavuus selkokielen teorian taustalla}

Saavutettavuus (engl. accessibility, saks. Barrierefreibeit, suomeksi usein myös esteettömyys) on alun perin kansainvälisen vammaisliikkeen kehittämä käsite, jolla kuvataan erityisesti vammaisten henkilöiden toimintamahdollisuuksia yhteiskunnassa. Saavutettavassa yhteiskunnassa pyörätuolilla pääsee sisään rakennukseen, liikennevaloissa on äänitunnisteet ja luentosalissa induktiosilmukka. Saavutettavuus koskee myös kognitiota eli ihmisten mahdollisuuksia saada tietoa ja ymmärtää. Tältä kognitiivisen saavutettavuu- 
den alueelta kieli löytää luontevasti paikkansa, vaikka sitä ei ole Suomessa eikä muuallakaan kovin tarkasti määritelty. Yleisesti kielen saavutettavuuden voidaan katsoa koskevan kaikkea, mikä yhteiskunnassa tapahtuu kielellisesti tai kielen välityksellä, esimerkiksi viestintää ja kommunikointia. Käytännössä kielellinen saavutettavuus voi olla sitä, että jostakin kielellisestä sisällöstä on saatavilla useita kieliversioita, vaikkapa suomi, ruotsi, pohjoissaame, farsi, somali, viittomakieli ja selkokieli (Leskelä, 2019, s. 48-77).

Saavutettavuuden painoarvo on viime vuosina kasvanut sekä kansainvälisesti että Suomessa $Y K: n$ vammaissopimuksen solmimisen ja ratifioinnin myötä. Sillä on ollut myös huomattava vaikutus selkokielen kehittämiseen ja edistämiseen eri maissa (esim. Bredel \& Maaß, 2016b, s.18-19; Gross, 2015; Lang, 2019; Leskelä, 2019, s. 50-51; Maaß, 2015, s. 20-21; Maaß \& Rink, 2019; Schädler \& Reichstein, 2015). Sopimuksen yhdeksännessä artiklassa, joka käsittelee saavutettavuutta ja esteettömyyttä, mainitaan myös viestintä, tiedotus ja sähköiset palvelut. Sopimuksen määritelmissä viestintään kuuluu myös selkokieli (YK-liitto.fi). Saksassa tämä on johtanut siihen, että selkokieli mainitaan myös tietyissä laeissa (Bredel \& Maaß, 2016a, s. 68-81; Bredel \& Maaß, 2016b, s. 16-21). Suomessa selkokieli mainitaan hallituksen esityksessä laiksi digitaalisten palveluiden tarjoamisesta (finlex.fi).

Kielellisen saavutettavuuden idea on taustalla myös selkokielen jakamisessa vaikeustasoihin. Jotta sama teksti olisi mahdollisimman monen kielellisesti heikossa asemassa olevan henkilön käytettävissä, keskimääräiselle lukijalle tuotettu selkoversio ei välttämättä ole tarpeeksi helppo tai tarpeeksi haastava ja oppimaan innostava. Osa lukijoista tarvitsee erittäin helppoa selkokieltä, jossa käytetään kaikkein yleisintä sanastoa ja rakenteita, ehkä äänellä tai kuvin tuettuna. Osalle taas tällainen tekstin yksinkertaistaminen ei ole tarpeen tai se voi jopa heikentää lukumotivaatiota (Leskelä, 2019, s. 160-172).

\section{SELKOKIELTÄ ERI VAIKEUSTASOILLA}

Kysymys selkokielen sopivasta vaikeustasosta on askarruttanut selkokielen kehittäjiä monissa maissa (Leskelä, 2019, s. 162-163). Missään maassa ei ole toistaiseksi käytössä laajamittaista jakoa eri vaikeustasoihin, mutta osittaisia tai tiettyjä tekstilajeja koskevaa kategoriointia on tehty muun muassa Ruotsissa, Norjassa ja Itävallassa (esim. llforlaget.se; nyponforlag.se; boksok.no; Fröhlich, 2017).

Ruotsissa selkokielistä kirjallisuutta on jo pitkään jaettu kolmelle vaikeustasolle (lätt, lättare ja lättast $)^{5}$. Ruotsin selkokirjoja tarkastelemalla voi päätellä, että jaon kriteerit ovat sekä kielellisiä että visuaalisia (Leskelä, 2019, s.162). Lättast-tason kirjoissa on paljon kuvia ja hyvin vähän tekstiä, teksti on rakenteiltaan ja sanastoltaan mahdollisimman yksinkertaista ja lauseet lyhyitä. Tekstimäärä ja sen kompleksisuus kasvavat seuraavilla tasoilla asteittain siten, että lätt-tason kirjoissa on jo lukuromaaneja. (llforlaget.se).

Norjan vaikeustasojako perustuu siihen, tarvitseeko lukija sisällöllisesti ja kielellisesti vai vain kielellisesti yksinkertaistettua tekstiä. Sisällöllisesti yksinkertaistettu (enkelt innhold) selkoteksti soveltuu esimerkiksi kehitysvammaisille lukijoille, kun taas kielellisesti yksinkertaistettu (litt å lese) on suunnattu ennen kaikkea maahanmuuttajille, jotka opiskelevat norjaa. Jako koskee vain selkokirjallisuutta. (boksok.no).

Itävallan jako perustuu eurooppalaisen

\footnotetext{
5 Jotkut kustantamot käyttävät Ruotsissa myös neli- tai viisiportaista vaikeustasojakoa (Leskelä, 2019, s. 162; nyponforlag.se).
} 
kielitaidon viitekehyksen kolmeen ensimmäiseen kategoriaan eli selkokieltä tuotetaan kielitaitotasoille A1, A2 ja B1. Jako on sikäli erikoinen, että selkokieli (Leicht lesen) määritellään Itävallassa kielimuodoksi, joka on suunnattu ensisijaisesti kehitysvammaisille henkilöille, vaikka vaikeustasojaottelu perustuu toisen tai vieraan kielen oppimisen prosessiin (vrt. Candussi \& Fröhlich, 2015; Fröhlich, 2017).

Mikään edellä kuvatuista jakoperusteista ei sovellu kovin hyvin Suomeen. Osa vaikeustasojaoista koskee vain kirjallisuutta (Norja, Ruotsi), toiset ottavat huomioon vain yhden selkokielen kohderyhmän (Itävalta). Suomen vaikeustasojen tulisi koskea kaikkia selkotekstejä ja kohderyhmiä, olla lingvistisesti perusteltavissa ja lisäksi helposti toteutettavissa käytännössä. Kaksi viimeistä voivat olla ristiriidassa keskenään: mitä tarkemmin perusteltu ja määritelty kriteeristö luodaan, sitä vähemmän se joustaa käytännössä, kun selkojulkaisuja tuotetaan. Tämä voi vähentää selkojulkaisujen tuotantomäärää, jos julkaisijat kokevat kriteerit kahlitseviksi (Leskelä, 2019, s. 161).

Selkokielen vaikeustasoihin liittyy kysymyksiä, joita on hyvä pohtia tarkasti ennen kuin vaikeustasojakoa sovelletaan käytännön julkaisutoimintaan Suomessa. Vaikka tasoja ei ole tarkoitettu arvojärjestykseen, ne saatetaan kokea sellaisiksi. Voivatko lukijat esimerkiksi suhtautua helpon tason selkokieleen kielteisesti? Selkokielen saatetaan pelätä leimaavan tai stigmatisoivan tarvitsijoitaan, tai siihen voidaan liittää kielteisiä käsityksiä kielen turmeltumisesta (esim. Bock \& Lange, 2015; Bredel \& Maaß, 2019, s. 260, 262-265; Bredel \& Maaß, 2016a, s. 45-55; Schädler \& Reichstein, 2015; Zurstrassen, 2017). Tasojärjestelmästä ei saisi tulla lisätaakkaa heikosti lukeville henkilöille.
Tässä artikkelissa esittelemäni vaikeustasojako on hypoteesi, joka pohjautuu yhtäältä selkokielen mittarin kehittämistyöhön ja toisaalta Selkokeskuksen asiantuntijoiden tekstianalyyseihin, joita olen saanut käyttööni. Koska tasoja ei ole aikaisemmin Suomessa määritelty, aiheesta ei ole vielä tutkimusta eikä tarkasteltuja selkotekstejä ole kirjoitettu tietoisesti jollekin tasolle. Vaikeustasojen määritelmät ja kriteeristö ovat näin ollen alustavia. Lähtökohtana ovat seuraavat yleiset luonnehdinnat tasoista ${ }^{6}$ : Perusselkokieli on selkokielen yleistaso, jota selkokielen mittari pyrkii mittaamaan (ks. luku 3). Se on kielellisesti vaikeudeltaan keskitasoista, ja se on suunnattu laajasti selkokieltä tarvitseville ihmisille. Helppo selkokieli tavoittelee kaikkein yksinkertaisinta kielellistä ilmaisua ja sopii heikoimmille lukijoille. Vaativa selkokieli taas tavoittelee edeltäviä tasoja vaativampaa ja monimuotoisempaa kielellistä ilmaisua, ja se on suunnattu lukijoille, joilla on lievempiä kielen ja lukemisen vaikeuksia (mutta joille yleiskieli edelleen on liian vaativaa) (Leskelä, 2019, s. 161).

Esittelen ensin perusselkokieltä selkokielen mittarin kriteerien valossa. Sen jälkeen luon katsauksen helpon ja vaativan selkokielen tason piirteisiin, joita selkokielen mittarilla ei toistaiseksi voi arvioida. Havainnollistan kaikkia kolmea tasoa esimerkkiteksteillä, jonka olen muokannut eri vaikeustasoille seuraavasta yleiskielisestä tekstikatkelmasta:

\footnotetext{
6 Selkokielen vaikeustasojen nimet ovat herättäneet keskustelua asiantuntijoiden parissa. Kaiken selkokielen tulisi olla helppoa, joten vaativa selkokieli on käsitteenä hämmentävä. Tasoille on ehdotettu myös numerointia tai värikoodausta, joka erottaisi ne toisistaan. Tässä artikkelissa käytän näitä nimiä tasoista, vaikka ne jatkossa saattavat muuttua.
} 


\section{Matkailijan terveysopas \\ [Yleiskielinen esimerkkiteksti]}

Kaikkien matkailijoiden, matkanjärjestäjien ja terveydenhuollon ammattilaisten yhteinen tavoite on matkailu ilman terveyshaittoja. Eksoottinen infektiotauti on harvoin matkailijan vastoinkäymisenä, sen sijaan turistiripuli tai odottamaton tapaturma pilaa matkan sitäkin useammin. (THL, 2018.)

\subsection{Perusselkokielen suuntaviivoja}

Perusselkokieli on tarkoitettu laajasti selkokielen pääkohderyhmille (kohderyhmistä ks. Leskelä, 2019, s. 97-102; Leskelä \& Lindholm, 2012; Leskelä 2012; Leskelä \& Kulkki-Nieminen, 2015, s. 22-32; Virtanen, 2009, s. 37-61). Se on selkokielen mittarin taso, jossa määritellään tyypillisen selkokielisen aineiston kielelliset kriteerit, jonkinlainen normitaso. Perustasolla voidaan julkaista useita eri tekstilajeja.

Matkailijan terveysoppaan esimerkki (ks. edellä) voisi perusselkokielellä kuulua näin:

Matkailijan terveysopas [perusselkokieli] Matkailijan on hyvä ottaa huomioon, että hän voi sairastua matkalla. Matkailijat sairastuvat usein tavallisiin tauteibin. Esimerkiksi ripuli on yleinen matkatauti. Matkalla voi myös tapahtua jokin onnettomuus. Joskus matkailija voi saada taudin, joka on harvinainen Suomessa. Tällaisia tauteja ovat esimerkiksi malaria tai dengue-kuume. Matkailijat kuitenkin sairastuvat niibin harvoin.
Seuraavaksi tarkastelen tässä esimerkissä toteutettuja sisällöllisiä, sanastollisia ja rakenteellisia muokkauksia, jotka mainitaan myös selkokielen mittarissa ${ }^{7}$ sekä myös osassa selkosuomen ohjeistuksissa.

\subsubsection{Tekstin sisällöllinen muokkaus perusselkokielen tasolla}

Esimerkkiin on tehty useita sisällöllisiä muokkauksia. Otsikon mukaan kyseessä on matkailijan terveysopas, joten selkoversio on suunnattu vain matkailijalle (matkanjärjestäjä ja terveydenhuollon ammattilaiset on jätetty pois) (selkotekstin suuntaamisesta lukijaryhmille ks. Bredel \& Maßß, 2016a, s. 506-509; Leskelä, 2019, s. 94-95, 116-117, 121-123; Virtanen, 2009, s. 73). Myös selkokielen mittarissa mainitaan, että tekstin aiheen tulee olla lukijalle mielekäs ( $\mathrm{k} 6$ ) ja sitä on käsiteltävä lukijan näkökulmasta $(\mathrm{k} 7)$.

Esimerkistä on karsittu lähtötekstin ajatus kaikkien yhteisestä tavoitteesta välttää terveyshaittoja - sen sijaan siinä todetaan, että matkailijan on varauduttava mahdolliseen sairastumiseen. Poistettu on myös lähtötekstin viittaus tapaturman odottamattomuuteen sekä matkan pilalle menemiseen. Selkotekstissä sisältöjen karsimisen tavoitteena on tekstin lyhentäminen sekä selkeyttäminen. Kun informaatiota vähennetään, lukijan kannalta olennaisimmat sisällöt saadaan selvemmin esille (Leskelä, 2019, s. 118-119; Virtanen, 2009, s. 77-79). Informaation määrää selkotekstissä koskevat selkokielen mittarin seuraavat kriteerit: Tekstissä on sopiva määrä informaatiota (ei liikaa) (k12), tekstistä ei puutu olennaista informaatiota (k13) ja tekstissä on ennakoitu, millaista tietoa ja kuinka paljon lukija sitä tarvitsee (k14). Toisaalta esimerkkiin ei ole jäänyt sisällöllisiä aukkoja, joita selko-

\footnotetext{
7 Viittaan mittarin kriteereihin merkinnällä ( $\mathrm{k}+$ kriteerin numero).
} 
lukija ei osaisi mielessään täydentää (Leskelä, 2019, s. 119; Virtanen, 2009, s. 79-80) (k26).

Lähes kaikki selkokielen ohjeet, sekä suomalaiset että kansainväliset, sisältävät kehotuksen kirjoittaa lyhyitä lauseita ja ilmaista vain yksi tärkeä asia yhdessä lauseessa $(\mathrm{mm}$. Bredel \& Maaß 2016b, s. 101-121; IE, 2009, s. 11; Leskelä, 2019, s. 151; NLS, 2013, s. 18, Sainio \& Rajala, 2002; Virtanen, 2009, s. 97). Kun sisältöjä karsitaan ja lauseita lyhennetään, tekstin sidosteisuus voi kärsiä. Esimerkiksi pelkistä lyhyistä päälauseista koostuva kokonaisuus voi olla vaikealukuinen, jos lukija ei hahmota, miten lauseet liittyvät toisiinsa (Leskelä, 2019, s. 120; 157-158; Leskelä \& Kulkki-Nieminen, 2015, s. 41, 50; Kulkki-Nieminen, 2002). Mittarin mukaan selkotekstin sisäinen sidosteisuus on hyvä silloin, kun lukija huomaa vaivatta esimerkiksi tekstin ilmaisemat syy-seuraussuhteet, ajallisesti peräkkäiset ja ehdollisesti toisistaan riippuvat asiat (k23). Jotta lukijan olisi helppo hahmottaa, miten sisällöt liittyvät toisiinsa, esimerkkitekstin selkoversioon on lisätty useita sidoselementtejä ( $\mathrm{mm}$. konjunktio että, partikkeli myös, konnektoiva lauseenalkuinen esimerkiksi, toistoa ja pronominiviittauksia tauti > tällaisia tauteja sekä vastakkaisuutta ilmaiseva kuitenkin).

Yleiskielisen esimerkin kappale (jossa on kaksi virkettä) on jaettu selkotekstissä kahdeksi kappaleeksi (joissa yhteensä seitsemän virkettä). Selkokielen mittarin mukaan tekstiä on jäsenneltävä niin, ettei se ole liian tiivistä (k15), ja jaettava se lukijalle sopivankokoisiin kokonaisuuksiin (k21, k22).

Myös lähtötekstin sävy on muuttunut muokkausprosessissa. Selkoteksti on sävyltään lähtötekstiä neutraalimpi ja opastavampi. Lähtötekstissä on nähtävissä useita sävyjä, esimerkiksi jonkinlaista ylevää visiointia $(y b$ teinen tavoite matkailu ilman terveyshaittoja) sekä vakavan asian keventämistä tietynlaisella kepeydellä (tauti matkailijan vastoinkäymise- $n \ddot{a}$, ripuli tai tapaturma matkaa pilaamassa). Sävyjen katoaminen tai yleissävyn muuttuminen on selkomuokkauksessa yleistä ja usein jonkin verran ongelmallista, sillä silloin voidaan menettää jotakin alkuperäisestä tekstistä (Leskelä, 2019, s. 121-124; Leskelä \& Kulkki-Nieminen, 2015, s. 129-130). Sävyn muuttamiselle selkotekstissä on oltava hyvät perusteet. Tässä peruste liittyy tekstin päätavoitteen kirkastamiseen. Tavoite on kertoa matkailijalle tärkeää tietoa matkasairauksista, mihin ylevä sävy ja piilohuumori on hankalasti yhdistettävissä (Leskelä \& Kulkki-Nieminen, 2015, s. 125). Selkolukijalle tällaiset sävyt eivät välttämättä hahmotu. Kun tekstin sisältöjä yksinkertaistetaan ja asioita käsitellään mahdollisimman havainnollisesti, tekstin sävy voi muuttua myös holhoavaksi tai vähätteleväksi (Leskelä \& Kulkki-Nieminen, 2015, s. 127-131). Mittarin mukaan tekstin sävyn on oltava sen tavoitteiden kannalta sopiva (k16), sävy ei saa ilmaista lukijan aliarvioimista (k18) ja siinä on otettava huomioon lukijan ikä (k19).

\subsubsection{Tekstin sanaston muokkaus perusselkokielessä}

Useimmissa selkokielen kansainvälisissä kriteeristöissä kirjoittajaa kehotetaan käyttämään tuttua sanastoa (NLS, 2013), yleisesti tunnettua sanastoa (IE, 2009) sekä tavallisesti käytettyä sanastoa (BITV 2.0 -asetus, 2011) (ks. myös Bredel \& Maaß2016a, s. 345-347). Myös Suomen ohjeissa korostetaan yleisen ja lukijakunnalle tutun sanaston merkitystä (esim. Kartio, 2009; Leskelä, 2017; Leskelä, 2019, s. 131-136; Leskelä \& Kulkki-Nieminen, 2015, s. 48-49; Virtanen, 2009, s. 82-86). Selkokieliseen esimerkkiin on valittu yleistä ja konkreettista sanastoa, joka on arvioitu kohderyhmälle tutuksi $(\mathrm{k} 33,36)$. Terveyshaittojen sijaan käytetään sanaa tauti, turistiripulin sijaan on vain ripuli ja tapatur- 
ma on korvattu onnettomuudella. Lukijalle vaikeaksi arvioitu eksoottinen infektiotauti on korvattu kahdella virkkeellä:Joskus matkailija voi saada taudin, joka on harvinainen Suomessa. Tällaisia tauteja ovat esimerkiksi malaria tai dengue-kuume. Jälkimmäinen lause on tyypillinen selkotekstin lisäys, jolla vaikeaa sanaa tai asiaa pyritään konkretisoimaan esimerkillä (Leskelä, 2019, s. 132-136, 140) (k36, 37).

Tunnistaakseen lukijalle tutut ja vieraat sanat selkokirjoittaja tarvitsee tietoa siitä, millaisella sanavarastolla selkolukija toimii (Leskelä, 2019, s. 128-130). Tästä on kuitenkin melko vähän tutkimusta. Sanan yleisyyttä voi tarkastella frekvenssisanastojen kautta, mutta on muistettava, että ne heijastavat lähinnä sitä tekstikorpusta, jonka pohjalta ne on laadittu. Siksi niissä voi esiintyä sanastoa, jota selkokielen kohderyhmät kohtaavat harvoin (Leskelä, 2019, s. 131). Frekvenssisanastot auttavat erottamaan frekvenssiltään hyvin kaukana toisistaan olevia sanoja (esim. auttaa vs. fasilitoida), mutta onko esimerkissä lähtötekstin sana matkailija tutumpi vai vieraampi selkolukijalle kuin vaikkapa matkustaja? Tärkeämpää kuin sanan sijoitus frekvenssilistalla, on sen keskeisyys kohderyhmien elämänalueilla (Bock, 2019, s. 35-39; Bredel \& Maaß, 2016a, s. 342), minkä arvioiminen on vaativaa ja edellyttää selkokielen kohderyhmien tuntemista. Lisäksi sanan yleisyyteen vaikuttaa se, voiko sanaa pitää merkitykseltään prototyyppisenä (Bredel \& Maaß, 2016a, s. 345-347). Prototyyppinen sana sijaitsee semanttisen merkityskentän keskiössä, ja sillä voi korvata kentän reunalla olevia sanoja, esim. auto on prototyyppinen sana, jolla voi useammin korvata sanan kulkuväline tai kottero kuin päinvastoin (Leskelä, 2019, s. 133-134).

Selkokielen mittarin mukaan lukijalle vieraaksi oletettu sana pitää selittää, jos sitä ei voi välttää (k37). Esimerkkitekstissä oletetaan, että lukija ei välttämättä ymmärrä, mitkä voivat olla tavallisia matkatauteja, joten niitä selitetään esimerkillä ripuli. Toisaalta mittarin mukaan ei pidä selittää sanoja, joita voi pitää lukijalle tuttuina (k38). Tekstissä ei selitetä esimerkiksi sanoja matkailija, sairastua ja onnettomuus.

Selkokielen mittarin mukaan tekstissä on suosittava lyhyitä sanoja (k34), joskaan ei lyhenteitä (k50). Selkokielisessä esimerkissä on keskimäärin 6,9 kirjainta/sana, ja noin 25 $\%$ sanoista on pitkiä, yli 10 kirjaimen sanoja. Yleiskielisessä lähtötekstissä on keskimäärin 9 kirjainta/sana, ja noin $43 \%$ sanoista on pitkiä. Yhdyssanoja selkotekstissä on 3, yleiskielisessä 8. Selkotekstissä käytetään siis pääosin jonkin verran yleiskielistä versiota lyhyempiä sanoja.

\subsubsection{Perusselkokielen morfosyntaktisia periaatteita}

Suomen monipuolinen taivutusjärjestelmä on selkolukijalle yleensä haaste (Leskelä, 2019, s. 23-24, Leskelä, 2015; Leskelä \& Kulkki-Nieminen, 2015, s. 49; Virtanen, 2009, s. 95), mitä ei ymmärrettävästi ole juuri käsitelty muiden maiden selko-ohjeissa. Selkosuomen mukauttajan on pakko olettaa tietyt perusrakenteet lukijalle tutuiksi voidakseen kirjoittaa yhtään mitään, mutta mitkä?Ja mitä tekstille tapahtuu, jos tiettyjä rakenteita ei käytetä? Aikaisemmissa Suomen selko-ohjeissa vaikeita morfosyntaktisia rakenteita ei varsinaisesti kielletty, vaan niiden käyttöä kehotettiin välttämään (Virtanen, 2009, s. 9497). Voi kuitenkin olla, että jotkin rakenteet ovat suomen kielessä niin vaikeita, että niiden käyttö pitäisi ainakin helpossa selkokielessä kieltää kokonaan (Leskelä, 2019, s. 166-167).

Selkokielistä esimerkkiä on muokattu etenkin syntaktisten rakenteiden osalta. Lähtötekstin kaksi virkettä ja kolme lausetta on jaettu seitsemään virkkeeseen ja yhdeksään lau- 
seeseen, joten sekä virkkeet että lauseet ovat lyhyempiä kuin lähtötekstissä (Leskelä, 2019, s. 154) (k68,69,71). Selkotekstin lauserakenteet noudattavat pääosin muotoa subjektipredikaatti-objekti / muut määritesanat ( $\mathrm{mt}$ : s. 151-152) (k73). Suomen selko-ohjeiden mukaan tekstin ei perusselkokielen tasolla tarvitse kuitenkaan muodostua pelkistä lyhyistä päälauseista, sillä niissä tekstin sidosteisuus on usein heikkoa, vaan sivulauseita on perusselkokielessä mahdollista käyttää tietyin rajoituksin (Leskelä, 2019, s. 87; Leskelä \& Kulkki-Nieminen, 2015, s. 49-50; Virtanen, 2009 , s. 101) $(\mathrm{k} 72,75,76)^{8}$. Esimerkissä on viisi päälause- ja kaksi päälause-sivulause-virkettä. Lauseissa on keskimäärin viisi sanaa, virkkeissä seitsemän sanaa. Predikaatit sijaitsevat enimmäkseen lauseen alkupuolella. Näin ollen tekstissä noudatetaan selkokielen mittarin lause- ja virkepituutta sekä niiden rakenteita koskevia kriteerejä $(\mathrm{k} 68,69,71,72,73)$.

Selkokielen mittarissa mainittuja verbi- ja nominirakenteiden kriteerejä (k53-58) esimerkki noudattaa hyvin, mutta niin noudattaa yleiskielinenkin teksti. Selkomuokkausta ei siten ole tarvittu. Sama koskee myös muutamia lausekkeisiin $(k 59,60)$ sekä infinitiivi- ja partisiippirakenteisiin ja pronominiviittauksiin liittyviä kriteerejä (k61,62).

Suomen morfosyntaktisen kompleksisuuden vuoksi selkokielessä on toisinaan noudatettava pienimmän pahan periaatetta. Jos jonkin asian voi sanoa vähän helpommalla rakenteella, sitä kannattaa käyttää, vaikka sekään ei olisi kaikkein yksinkertaisin. Vaikeiden rakenteiden välttäminen ei kuitenkaan saa johtaa epäluonnollisiin lauserakenteisiin tai monimutkaiseen teemankulkuun (KulkkiNieminen, 2010, s. 180-181, 189-192; Leskelä \& Kulkki-Nieminen, 2015, s. 118-121;

8 Osa kansainvälisistä selko-ohjeista kieltää sivulauseet kokonaan (ks. esim. IE, 2009, s.17; Bredel \& Maaß, 2016, s. 348; Maßß, 2015, s. 109).
Uotila, 2012) (k74). Perusselkokielen tasolla selkokielen on oltava hyvää suomea, sillä sen tavoitteena on tarjota lukijalle myös malleja kirjallisesta kielenkäytöstä (vrt. selkokielen pedagoginen funktio, ks. esim. Bredel \& Maaß, 2016a, s. 56-58; Bredel \& Maaß, 2016b, s. 10-11). Selkokielen mittarin ensimmäinen kriteeri kehottaa noudattamaan yleiskielen oikeinkirjoitussuosituksia (k1).

\subsection{Helpon selkokielen suuntaviivoja}

Helpon selkokielen tasolla on Suomessa tuotettu vain vähän tekstejä eikä siitä ole juuri tutkimusta. Siksi sen periaatteita ei toistaiseksi pysty kuvaamaan yhtä tarkasti kuin perusselkokielessä, eikä sitä voi mitata selkokielen mittarilla. (Leskelä, 2019, s. 114). Sen sijaan kuvauksessa voidaan tukeutua muutamiin julkaisuihin, joissa on tavoiteltu mahdollisimman yksinkertaista selkokieltä ja jotka on suunnattu kaikkein heikoimmille kielenkäyttäjille. Tällaisia ovat esimerkiksi Selkosanomien kuvauutiset (selkosanomat/kuva), Yleisradion aiemmin julkaisemat Tosi helpot uutiset (selkouutiset/tosihelppo) sekä muutamat selkokirjat (esim. Säpinät-kirjasarja, Sainio, 2014). Vertaamalla näitä aineistoja perusselkokielen tasoon voidaan hahmotella helpon selkokielen kriteerejä. Lisäksi voidaan tarkastella ohjeita suhteessa saksankielisen alueen selkokielen määrittelyyn (Leichte Sprache) sekä Ruotsin lättast-tason selkokirjoihin.

Edellä yleiskielellä ja perusselkokielellä esitetty esimerkki Matkailijan terveysoppaasta muuttuu selkokielen helpolla tasolla radikaalisti: 


\section{Tietoa matkailijalle}

[Esimerkki helpolla selkokielellä]

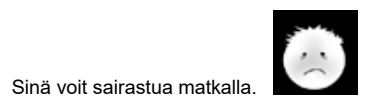

Voit esimerkiksi saada ripulin.

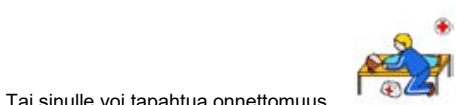

Tai sinulle voi tapahtua onnettomuus.

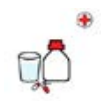

Ota matkalle mukaan lääkkeitä.

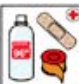

Ota matkalle mukaan myös laastaria ja puhdistusainetta.

\section{i}

Ydinajatus helpolla tasolla on tukea lukijan ymmärtämistä kaikin keinoin. Kielimuotona helppo selkokieli on perusselkokieltä rajatumpi ja periaatteiltaan ehdottomampi, ja tässä mielessä muistuttaa selkosaksaa koskevia sääntöjä (ks. esim. Bredel \& Maaß, 2016a; Leskelä, 2019, s. 163, 165). Helpolla tasolla tekstissä voidaan käyttää kuvatukea, esimerkiksi lauseen tai kappaleen avainsanojen kuvittamista tai äänitukea (mt. 204-207). Esimerkkitekstissä kuvat antavat vihjeitä esimerkiksi sanojen ripuli tai pubdistusaine ymmärtämiseen.

Edeltävässä esimerkissä sisältöjen käsittelytapa ja sävy on muuttunut melkoisesti. Helppo versio muistuttaa jossain määrin muistilistaa, jossa luetellaan matkustamiseen liittyviä kielteisiä asioita ja varoituksia. Muistilistamainen sisältö on perusteltu tekstin tarkoituksella: tarkoitus on kuvata vain lähtötekstin tärkeimmät sisällöt lukijalle, kaikki ylimääräinen ja lukijaa mahdollisesti rasittava on karsittu pois. Samalla kuitenkin myös lähtötekstin jonkinasteinen kepeys ja ylevyys ovat poissa. Bredel ja Maaß (2016b, s.
11) mainitsevatkin erityisesti kielivitsit ja sanaleikit esimerkkeinä tekstiominaisuuksista, jotka käytännössä karsiutuvat pois, kun teksti muokataan yleiskielestä selkosaksaksi.

Helpossa selkokielessä korostuu lukijan näkökulma vahvemmin kuin perusselkokielessä. Teksti on nyt sinä-muodossa, joka kohdentaa sen suoraan lukijalle (Leskelä, 2019, s. 121-122, 165; ks. myös IE, 2009). Teksti koostuu lähinnä lyhyistä päälauseista. Tältä osin se on linjassa selkosaksan lauserakenteita koskevien sääntöjen kanssa (Bredel \& Maaß, 2016b, s. 101; IE, 2009, s. 17; Maaß, 2015, s. 109-117). Sinä-muoto, lyhyet pälauseet (etenkin tekstin lopun kolme käskylausetta) sekä negatiivisten sisältöjen korostuminen vaikuttavat tekstin yleissävyyn: varsinkin nopeasti lukien teksti voi vaikuttaa lukijasta jopa tylyltä. Sävy ei kuitenkaan helpossa selkokielessä ole niin tärkeä kuin ymmärrettävyys (Leskelä, 2019, s. 163). Lisäksi lukutahti on todennäköisesti melko hidas, jolloin erilaisten sävyyn vaikuttavien piirteiden yhteisvaikutus jää vähäisemmäksi ${ }^{9}$. Lukija ei ehkä itse lainkaan lue tekstiä, vaan se luetaan hänelle tai hän lukee sitä yhdessä avustajan, opettajan tai läheisen kanssa, ja jokaisesta lauseesta ja kuvasta keskustellaan mahdollisesti lukutilanteessa erikseen (mt. 164).

Helppo selkokieli on tarkoitettu lukijoille, joiden kieli- ja lukutaito on hyvin heikko. Se voi tarkoittaa vaikeuksia mekaanisessa lukutaidossa eli kyvyssä saada selvää, miten kirjaimista muodostuu sanoja ja sanoista lauseita. On myös mahdollista, että lukija on mekaanisesti lukutaidoton. Tekstissä tulee ottaa huomioon sekä kielelliset että visuaaliset seikat, jotka helpottavat alkavan tai kehittyvän kieli- ja lukutaidon varassa olevaa henkilöä

\footnotetext{
9 Negatiivisten sisältöjen korostuminen on kuitenkin sikäli ongelma, että lukijan säikyttely ei liene tarkoituksenmukaista. Esimerkkitekstiin voisi lisätä vielä yhden lauseen, jossa ilmaistaisiin, että vakavia tauteja ja onnettomuuksia tapahtuu kuitenkin harvoin.
} 
(Leskelä, 2019, s. 165). Kehittyvän lukijan lukutaito alkaa esiaakkosellisesta vaiheesta, jossa hän voi tunnistaa muutamia sanoja tekstissä niiden visuaalisen muodon perusteella tutussa kontekstissa, mutta ei pysty lukemaan näitä sanoja muissa ympäristöissä. Vähitellen sanan tunnistus etenee aakkoselliseen vaiheeseen, jossa lukija oppii havaitsemaan äänne- ja kirjainvastaavuuden. Lopuksi seuraa automatisoitumisen vaihe, jossa lukeminen vähitellen sujuvoituu siinä määrin, että lukija selviytyy myös uusista sanoista, joita tekstissä tulee vastaan (esim. Ehri \& McCormick, 1998; selkosaksan sanojen tunnistamisesta Bock, 2019, s. 35-39; Bredel \& Maaß, 2017).

Kohderyhmä on tällä selkokielen tasolla määritelty tarkasti. Lukija tai kuulija voi olla alkeistason kielenoppija (A1-tasolla) tai puhe- tai kehitysvammainen henkilö, jolla on hyvin rajallinen kielitaito. Hän voi olla myös vaikeammin afaattinen henkilö tai muistisairas henkilö, jonka kielelliset taidot ovat vähitellen katoamassa (Leskelä, 2019, s. 164).

\subsubsection{Helpon selkokielen sanaston periaatteita}

Helpossa selkokielessä lähtökohtana ovat sanat, joita voidaan pitää tälle, tarkasti määritellylle lukijakunnalle helppona ja ymmärrettävänä: lyhyet, konkreettiset, merkitykseltään prototyyppiset sanat (Bredel \& Maaß, 2016a, s. 345-347; 2016b, s. 74), kohderyhmien arjessa usein toistuvat sanat sekä näiden sanojen toisto (Sainio \& Rajala, 2002; Virtanen, 2009, s. 84) sekä synonyymien välttäminen (Bredel \& Maaß, 2016b, s. 91-94). Esimerkkitekstin sanat ovat pääosin juuri tällaisia (voida, saada, ottaa, sinä, matka, lääke, lääkäri). Vaikea sana on tällä tasolla parempi karsia pois kuin käyttää tekstissä selitettynä, sillä ymmärrettävyyden vaatimus ohittaa pedagogiset tavoitteet opettaa lukijalle jotakin tiettyä sanastoa (Leskelä, 2019, s. 166-167).
Jonkinlaista vertailukohtaa helpoimmalle sanastolle voi hakea alkusanakielen teoriasta (Natural Semantic Metalanguage, ks. esim. Goddard \& Wierzbicka, 2018; Tissari \& Vanhatalo, 2017) sekä sen pohjalta kehitetystä minimikielen sanastosta, joka muodostuu niin sanotuista semanttisista molekyyleistä. Semanttiset molekyylit ovat alkusanoja laajempi joukko kielen sanastollista ydintä, joilla voidaan ilmaista suhteellisen yksinkertaisia ja inhimillisen ymmärryksen kannalta perustavanlaatuisia merkityksiä. Tällaisia ovat esimerkiksi ihmisruumiin osat ( $\not \ddot{a} \ddot{a}$, suu, käsi...), perhe- ja sukulaisuussuhteet (nainen, syntyä, isä...), biologinen maailma (olento, kasvaa), fysikaaliset ominaisuudet (pyöreä, pitkä, kova...) ja asento ja orientaatio (olla jonkin pä̈llä, alla, ympärillä...) (Goddard \& Wierzbicka, 2018).

Semanttisten molekyylien pohjalta tuotettu minimisanasto ei välttämättä riitä selkotekstissä helpollakaan tasolla (Leskelä \& Vanhatalo, tulossa). Aiheesta riippuen tekstissä on yleensä käytettävä myös muita sanoja. Kohderyhmille voi olla olennaista saada tietoa jostakin aiheesta, jolloin kyseiseen aihepiiriin liittyvää sanastoa voi olla vaikea välttää. Esimerkkitekstissä tällaista sanastoa ovat ainakin ripuli, laastari ja pubdistusaine. Vaikean sanan selittäminen on selkotekstissä riskialtista varsinkin helpolla tasolla, sillä selitystä lukiessaan lukijan on hypättävä pois tekstikontekstista ja palattava siihen selityksen jälkeen, mikä ei aina onnistu varsinkaan heikommilta lukijoilta (Leskelä, 2019, s.166).

\subsubsection{Helpon selkokielen morfosyntaktisia periaatteita}

On perusteltua, että helppoa selkokieltä koskevat tiukemmat morfosyntaktiset säännöt kuin perusselkokieltä, sillä lukijan heikko kieli- ja lukutaito sekä kognitiivisen kapasiteetin rajoitukset asettavat muita tasoja 
ahtaammat raamit kielenkäytölle (Leskelä, 2019, s. 97-101). Helpossa selkokielessä on esimerkiksi kielletty muotoja, joita perusselkokielessä on kehotettu lähinnä välttämään, esimerkiksi aikamuotojen liittomuotoja sekä kolmen lauseen virkkeitä (mt. 166).

Helpon tason esimerkissä kielellisten rakenteiden määrä on varsin suppea. Esimerkissä käytetään yleisimpiä sijamuotoja yksikössä ja monikossa, ei essiiviä. Translatiivi on vain kiteytyneessä ilmaisussa esimerkiksi, muita harvinaisempia sijamuotoja ei ole lainkaan (esimerkiksi instruktiivia tai komitatiivia) (Leskelä, 2019, s. 142-143, 166). Verbien aikamuodoista käytössä on preesens ja moduksista indikatiivi ja imperatiivi. Vaikeita muotoja kuten menneen ajan liittomuotoja tai konditionaalia ja potentiaalia ei käytetä.

Lauseet on rakennettu finiittiverbin ympärille ja niissä on suora sanajärjestys. Lauseissa on keskimäärin viisi sanaa / lause. Lyhyet lauseet ja selkeät peruslauserakenteet ovat tällä tasolla erityisen tärkeitä, sillä hyvin heikko lukutaito on usein yhteydessä työmuistin ongelmiin, joten pitkien ja mutkikkaiden lauserakenteiden lukeminen ei yleensä onnistu (selkokielen kohderyhmien työmuistista ks. esim. Numminen, 2006; Uotila, 2019; Virtanen, 2009, s. 28-32). Esimerkkitekstissä on yksi päälause-sivulause-virke, muut virkkeet koostuvat päälauseista. Sivulauseiden käyttöä ei ole helpossakaan selkokielessä kielletty, mutta kirjoittajaa kehotetaan suosimaan päälauseita (Leskelä, 2019). Perusselkokielen syntaktisista periaatteista helpon selkokielen erottaa etenkin se, kuinka monta sanamäärältään vähän pidempää lausetta, lausemäärältään pidempää virkettä tai kompleksisempaa lauserakennetta lyhyessä tekstissä voi olla ( $\mathrm{mt}$. 166-167.)

\subsection{Vaativan selkokielen suuntaviivoja}

Vaativaa selkokieltä on selkokielen tasoista toistaiseksi kehitetty vähiten ainakin tietoisesti, eikä tästä vaikeustasosta ole juuri tutkimusta (Leskelä, 2019, s. 161). Vaativan tason määrittelyssä voidaan hyödyntää osaa selkokielen mittarin kriteereistä, mutta osa niistä ei ole relevantteja, sillä vaativalla tasolla selko-ohjeistukset ovat joustavia ja luonteeltaan harkinnanvaraisia suosituksia. Vaativaa tasoa voidaan määritellä myös tarkastelemalla olemassa olevia selkoaineistoja: Suomessa on 1990-luvulta lähtien julkaistu esimerkiksi helppolukuista kirjallisuutta sekä muutamia oppimateriaaleja, jotka ovat kieleltään vaativampia, mutta jotka ovat silti saaneet selkotunnuksen ja siten katsottu selkomateriaaleiksi.

Tarvetta perusselkokieltä vaativammalle ja lukijaa eteenpäin motivoivalle selkokielen tasolle näyttäisi olevan. Esimerkiksi edistyneet kielenoppijat tai sujuvasti lukevat kehitysvammaiset henkilöt eivät välttämättä koe kovin motivoivaksi perustason selkotekstiä, sillä se ei tarjoa heille kielellisiä ja sisällöllisiä haasteita. He tarvitsevat selkotekstejä, jotka toimivat ikään kuin siltana kohti yleiskieltä, avartaen heidän kielellistä tietoisuuttaan paitsi sanastossa ja rakenteissa myös uusissa tekstilajeissa ja erilaisissa kirjoitustyyleissä. Ja kuitenkin tekstin pitäisi olla vähän yleiskieltä helpompaa, jotta sen lukemisesta ei muodostu liian korkeaa kynnystä (Leskelä 2019, s. 169-170.) 
Vaativalla tasolla Matkailijan terveysopas voisi olla seuraavanlainen:

\section{Matkailijan terveysopas}

[Esimerkkiteksti vaativalla selkokielellä] Matkailijat, matkanjärjestäjät, lääkärit ja hoitajat toivovat, että kukaan ei sairastu matkalla. Niin voi kuitenkin käydä. Matkailija sairastuu harvoin harvinaiseen tartuntatautiin kuten vaikka malariaan. Sen sijaan matkailija saa usein ripulin tai hän voi joutua onnettomuuteen.

Vertailu yleiskieliseen lähtötekstiin osoittaa, että tekstiä on muokattu helpommaksi melko vähän. Sanastossa on pieniä muutoksia, esimerkiksi eksoottinen infektiotauti on harvinainen tartuntatauti. Vierasperäiset sanat on korvattu kotoperäisillä sanoilla - mikä tosin ei välttämättä ole hyvä ratkaisu, jos lukijoina on indoeurooppalaisia kieliä hallitseva maahanmuuttaja (Leskelä 2019, s. 132). Toisaalta välttämällä vierasperäisiä sanoja selkokirjoittaja voi tarjota lukijalle mahdollisuuden tutustua kotoperäiseen sanastoon.

Lähtötekstin ensimmäisessä virkkeessä puhutaan ybteisestä tavoitteesta, selkotekstissä kaikki toivovat. Tämän jälkeen on lisätty ylimääräinen lause Niin voi kuitenkin käydä. Se yhdistää ensimmäisen lauseen kolmanteen, sillä muuten kolmas lause vaikuttaisi vähän hämmentävältä - ensin toivotaan, ettei kukaan sairastu ja sitten matkailija sairastuu. Pitkiä virkkeitä on lyhennetty lähtötekstistä, mutta ne ovat selkokielen perustasoa pidempiä ja jonkin verran vaativampia. Lukijan oletetaan tällä tasolla jo selviävän vähän abstraktimmasta ilmaisusta sekä kasvavasta lauseen sana- ja informaatiomäärästä. (Leskelä, 2019, s. 171).

Vaativan selkokielen tasolla ei ole mielekästä antaa samanlaisia kieltolistoja kuin helpon selkokielen tasolla. Kirjoittajavoi vapaammin valita sellaista sanastoa ja sellaisia rakenteita, jotka sopivat tekstikokonaisuuteen ja tyyliin (mt. 170-171). Tältä osin vaativa selkokieli muistuttaa saksankielisten maiden Einfache Sprache -kategorian luonnehdintoja (Bock, Fix \& Lange, 2017; Bredel \& Maaß, 2016a, s. 528; Hallik \& Janssen, 2017). Tekstit voivat myös vaihdella vaikeustasoltaan muita tasoja enemmän. Vaativan tason esimerkissä alkulauseessa luetellaan kaikki lähtötekstissä mainitut henkilöt, joita opas koskee, joskin lähtötekstin terveydenhuollon ammattilaiset on muutettu muotoon lääkärit ja hoitajat. Tekstiä ei siis ole suunnattu yksiselitteisesti vain tietynlaiselle lukijalle, vaan laajemmalle, tarkemmin määrittelemättömälle lukijakunnalle. Selkotekstin pitää kuitenkin myös vaativalla tasolla olla yleiskieltä helpompaa.

\subsubsection{Vaativan selkokielen sanastollisia periaatteita}

Tavoitteena on, että tällä tasolla periaatteet ovat joustavia ja suosituksenomaisia. Lyhyitä ja yleisiä sanoja kannattaa suosia, mutta niiden lisäksi mukana voi olla vaikeampia sanoja eri aihepiireistä. Lukijalla on mahdollisuus laajentaa sanavarastoaan, kun uusia, vaativia sanoja esiintyy selkeässä ja vähän yleiskieltä helpommassa tekstiympäristössä (Leskelä 2019, s. 170-171).

Toisto ei ole yhtä tärkeää kuin perustasolla, mutta tekstin teeman kannalta olennaista sanastoa voidaan edelleen jossain määrin toistaa (mt. 171). Esimerkkitekstissä toistetaan muutaman kerran sanoja matkailija ja sairastua. Sanoja voidaan myös tarjota lukijalle useassa eri taivutusmuodossa, jos se sopii tekstiin muuten. Näin lukija saa mahdollisuuden tutustua sanaan eri muodoissa. Jos lukijoina on suomen kielen oppijoita, tämän tasoinen selkoteksti voidaan kytkeä tietyn kielitaitotason sanastollisiin tavoitteisiin. 


\subsubsection{Vaativan selkokielen rakenteisiin liittyviäperiaatteita}

Tällä tasolla lukija hallitsee kohtuullisesti suomen perusrakenteita, joten tekstissä voidaan käyttää kaikkia aikamuotoja, konditionaalia sekä passiivia. Kirjoittaja voi käyttää harkiten jotakin vaikeampaa rakennetta, jos muu tekstiympäristö on helppo, esimerkiksi yleistävää 3. persoonaa tai partisiippiattribuuttia (Leskelä, 2019, s. 122-123). Esimerkkitekstissä lauserakenne Näin voi kuitenkin käydä ei sisällä subjektia, mutta on kontekstissaan melko helposti ymmärrettävissä. Lukija voi tutustua vaikeampiin kielen rakenteisiin, joita hän kohtaa yleiskielisissä teksteissä. Samaan tekstiin ei kuitenkaan saa kasautua useita vaikeita rakenteita.

Helppoon ja perusselkokielen tasoon verrattuna vaativan tason lukija selviää jo vähän pidemmistä ja mutkikkaammista lauserakenteista. Lauseen pituuden on kuitenkin pysyttävä keskimäärin yleiskieltä lyhyempänä ja predikaatin sijoituttava ennemmin lauseen alku- kuin loppupuolelle (Leskelä, 2019, s. 170-171). Vaativan tason esimerkissä ensimmäisessä lauseessa predikaatti on lauseen lopussa, joten sitä voi pitää melko hankalana aloituslauseena, mutta sen jälkeen predikaatit sijaitsevat lauseen alkupuolella subjektin jälkeen. Aloituslause on opastaville teksteille tyypillinen aiheeseen johdatteleva lause, joten näin lukija saa mahdollisuuden tutustua tälle tekstilajille tavallisiin piirteisiin.

\section{SELKOKIELI MITTARISSA}

Edellä esitelty hahmotelma selkokielen vaikeustasoiksi pohjautuu selkokielen mittarin määrittelemään perusselkokielen tasoon. Seuraavaksi esittelen tämän mittarin kehittämisprosessia sekä arvioin sen käyttökelpoisuutta tekstien selkokielisyyden arvioinnissa.
Mittarin on kehitetty Selkokeskuksessa selkokielen asiantuntijoiden ja tutkijoiden apuvälineeksi, jolla voidaan osoittaa, vastaako jokin teksti selkokielen kriteerejä vai ei. Tällä hetkellä mittarissa on 80 selkokielen kriteeriä. Pääosin kriteerit eivät ole luonteeltaan ehdottomia, vaan useimmat niistä kehottavat joko suosimaan tai välttämään jotakin piirrettä. Yksittäinen kielen piirre on tekstin vaikeustason kannalta harvoin kovin ratkaiseva, joten selkokielisyyden arvioinnissa on tarkkailtava laajemmin tekstikokonaisuutta.

Mittari on kehitetty osana Selkokeskuksen selkokielen kehitystyötä. Sen taustalla vaikuttavat Suomen selkokirjoitusohjeistukset, jotka ovat vuosikymmenien aikana muotoutuneet nykyisenkaltaisiksi (ks. esim. Leskelä, 2019; Leskelä \& Kulkki-Nieminen, 2015; Virtanen, 2009).

\subsection{Selkokielen mittarin kehitystyö}

Selkokielen mittarin kehittäminen alkoi kokoamalla aiemmat selko-ohjeistukset mahdollisimman kattavaksi listaksi. Ohjeet ryhmiteltiin neljään osioon (tekstikokonaisuus, sanasto, kielen rakenteet sekä visuaalisuus ${ }^{10}$ ). Mittarille luotiin pisteytysjärjestelmä, jossa arvioija antaa jokaisen kriteerin täyttymisestä arvioimassaan selkotekstissä 1-3 pistettä (vastaa huonosti / vastaa osin / vastaa täysin selkokielen periaatteit $a$ ) tai 0 , jos kriteeri ei ole olennainen kyseisessä tekstissä.

Mittarin testauksiin osallistui yhteensä 18 Selkokeskuksen asiantuntijaa, jotka arvioivat kahdella testauskierroksella kolmen erilaisen informoivan tekstin selkokielisyyttä. Ensimmäisellä testauskierroksella asiantuntijat arvioivat migreeniä käsittelevää selkotekstiä mittarilla, jossa oli 20 kriteeriä. Näiden täyttymistä kyseisessä tekstissä asiantuntijat

\footnotetext{
${ }_{10}$ Mittarin visuaalisuutta koskeva osuus on rajattu tämän artikkelin tarkastelun ulkopuolelle.
} 
arvioivat asteikolla kokonaan / osittain / ei lainkaan. Arvioinneissa oli jonkin verran hajontaa, vaikka ehkä vähemmän kuin ensimmäisen testauskierroksen kohdalla olisi voinut odottaa. Eniten hajontaa oli niiden kriteerien kohdalla, jotka koskivat tekstin kokonaisrakennetta ja sanoja (erityisesti kielikuvien, sanontojen ja synonyymien käyttöä). Testauksen jälkeen näitä kriteerejä tarkennettiin ja uusia kriteerejä lisättiin. Yhtenevimpiä asiantuntijoiden arviot olivat kielen rakenteiden osalta. Rakenteiden arvioiminen on melko yksiselitteistä: tietty rakenne, vaikkapa lauseenvastike, joko on tai ei ole tekstissä. Sen sijaan on vaikeampaa arvioida, onko tekstissä sisällöllisiä aukkoja tai auttaako konteksti ymmärtämään tekstissä käytettyä kielikuvaa.

Vuosina 2016 ja 2017 mittaria kehitettiin yhdessä Kotimaisten kielten keskuksen kanssa. Tämän yhteistyön myötä mittarin kriteeristöä tarkennettiin sekä laajennettiin huomattavalla määrällä uusia kriteerejä, ja kriteerien sanamuotoja muokattiin yksiselitteisemmiksi. Muun muassa kriteereissä esiinty- neitä suhteuttavia sanoja (enimmäkseen, pääosin) vähennettiin, sillä asiantuntijat kokivat ne arvioinnin kannalta liian epämääräisiksi. Useisiin morfosyntaktisiin kriteereihin lisättiin konkreettisia esimerkkejä, jotta mittarin käyttö ei vaatisi vaikeiden kieliopillisten termien tunnistamista. Tavoitteeksi määriteltiin mittarin kehittäminen sellaiseksi, että sillä on mahdollista tavoittaa selkokielen perustaso.

Toisella testauskierroksella asiantuntijat arvioivat kahta eri tekstiä 54 kriteerin perusteella. Teksti 1 (aiheena perustietoa mentoritoiminnasta) vastasi Selkokeskuksen arvion mukaan melko hyvin selkokielen periaatteita. Teksti 2 (aiheena perustietoa kuntalaisuudesta) vastasi selkokielen periaatteita vähän heikommin. Näitä arvioita ei mainittu asiantuntijoille ennen arviointia. Arviointi tapahtui nyt pisteyttämällä kriteerin toteutuminen numeroilla 1 (kriteeri ei täyty), 2 (täyttyy osin) ja 3 (täyttyy täysin), ja lisäksi käyttöön otettiin myös 0 (ei ole olennainen kriteeri tässä tekstis$s \ddot{)}$. Asiantuntijoiden pisteytyksissä oli jonkin verran hajontaa.

TAULUKKO 1: Asiantuntijoiden pisteytyksen hajonta toisella testauskierroksella.

\begin{tabular}{|l|l|l|l|l|}
\hline Teksti & $\begin{array}{l}\text { Täysin yhtenevä } \\
\text { pisteytys }\end{array}$ & 1 pisteen ero & 2 pisteen ero & $\begin{array}{l}0 \text { (ei olennainen } \\
\text { kriteeri) }\end{array}$ \\
\hline Teksti 1 & $26 / 54$ & $13 / 54$ & $8 / 54$ & $7 / 54$ \\
\hline Teksti 2 & $22 / 54$ & $22 / 54$ & $5 / 54$ & $5 / 54$ \\
\hline
\end{tabular}

Tälläkin kierroksella asiantuntijoiden pisteytys oli yhtenevintä kielellisten rakenteiden kohdalla. Suurinta hajonta oli tekstin kokonaisrakenteen kriteerien kohdalla. Hajonnasta huolimatta tulosta voi pitää melko luotettavana, kun ottaa huomioon, että käsittelyssä on kielen- ja tekstinpiirteitä koskeva laadullinen analyysi, jossa täydellisen objektiiviseen tarkkuuteen ei juuri voi päästä.
Toinen testauskierros toi kuitenkin esille uuden, varsin mielenkiintoisen ongelman. Kun yksittäisten piirteiden pisteet laskettiin yhteen, mittari saattoi antaa positiivisen tuloksen jollekin kriteeriosiolle (esim. sanasto on selkokieltä), vaikka asiantuntijan yleisarvio ennen mittaria olisi tältä osin ollut kielteinen. Kun tekstiä siis pisteytettiin yksityiskohtaisesti, kokonaispisteet nousivat niin suureksi, 
että osio oli laskettava selkotekstiksi vastoin arvioijan omaa yleisarviota. Väärien positiivisten tulosten estämiseksi pisteytysäräjestelmää muutettiin siten, että kriteerit ryhmiteltiin kokonaisuuksiin, joille annettiin yhteispisteet. Kokonaisuuden osakriteerit arvioitiin mittarissa sen mukaan, toteutuuko osakriteeri tekstissä (+) vai ei (-). Tämän jälkeen arvioija laski kokonaisuudelle yhteispisteen, joka vaikuttaa kokonaistulokseen. Kymmenen kriteeriä jaettiin osakriteereiksi. Tämän muutoksen jälkeen väärät positiiviset vastaukset vähenivät. Toisen testauskierroksen tulosten pohjalta kriteerejä myös lisättiin siten, että kieleen liittyviä kriteerien määrä nousi 79:ään.

Mittarista on testauskierrosten, asiantuntijoilta kerätyn palautteen sekä Kotuksen konsultoinnin pohjalta tehty 19 versiota. Mittari julkaistiin lokakuussa 2018.

\subsection{Selkokielen ja yleiskielen erottaminen selkokielen mittarilla}

Mittarin suurimmaksi haasteeksi havaittiin lopulta se, miten se pystyy erottamaan yleiskielen selkokielestä. Mittarilla voi helposti tunnistaa ei-selkokieliseksi vaikkapa tieteellisen tekstin, joka sisältää abstraktia ja silminnähden kompleksista kieltä. Sen sijaan hyvää ja selkeää yleiskieltä sen on vaikeampi erottaa selkotekstistä. Monet mittarin piirteet kuvaavat jossain määrin myös yleiskieltä (esim. Tekstissä ei ole asiavirheitä, k2; Teksti etenee johdonmukaisesti, k20). Selkotekstissä näitä piirteitä viedään vain vähän pidemmälle. Selkokieli ja yleiskieli eivät ole varsinaisia kieliä, joilla on selkeät kielioppisäännöt, vaan kielimuotoja, joita voi lähinnä luonnehtia ja kuvata joustavilla ja suhteellisilla periaatteilla. Tarkan rajan vetäminen yleiskielen ja selkokielen välille on yhtä vaikeaa kuin vetää selkeä raja murteen ja yleiskielen välille. On asioita, jotka erottavat näitä kielimuotoja, mutta niillä on myös paljon yhteistä maaperää.
On myös huomattava, että kaikista kielimuodoista esiintyy kielellisesti helpompaa ja vaikeampaa varianttia. Esimerkiksi virallinen vaaratiedote on, tai ainakin sen pitäisi olla, sekä sanastoltaan että rakenteiltaan melko yksinkertaista yleiskieltä. Sen sijaan vaikkapa viranomaisen etuuspäätös voi olla kieleltään vaativaa lakiviittauksineen ja erikoissanastoineen, mutta sekin on ainakin periaatteessa yleiskieltä. Samoin selkokielessä on variaatiota: on hyvin helppoa kieltä niille lukijoille, joilla on kaikkein suurimmat kielelliset ongelmat, ja vähän vaativampaa kieltä lukijoille, joiden kielelliset ongelmat ovat lievempiä. Käytännössä on siis todennäköisesti tilanteita, joissa yleiskieleksi laskettava teksti on kielellisesti helpompaa kuin selkokieleksi laskettava vaativampi teksti (Leskelä, 2019, s. 169-172). Mikä siis erottaa selkokieltä yleiskielestä, jos ei kielen helppous? 


\subsubsection{Lukijalle kohdennettu kieli}

Yksi selkokielen ja yleiskielen ero liittyy kielen kohdentamiseen. Selkokieli eroaa muista kielimuodoista paitsi kielen helppouden suhteen myös siinä, että se pyritään kohdentamaan kohderyhmälle, jolla on kielellisiä vaikeuksia (Kulkki-Nieminen, 2002; Leskelä, 2019, s. 94-95). Nelikentässä tarkasteltuna selkokieli asettuu siis siihen osioon, jossa kieli on kaikkein yksinkertaisinta ja ottaa lukijansa tarpeet ja osaamisen parhaiten huomioon:

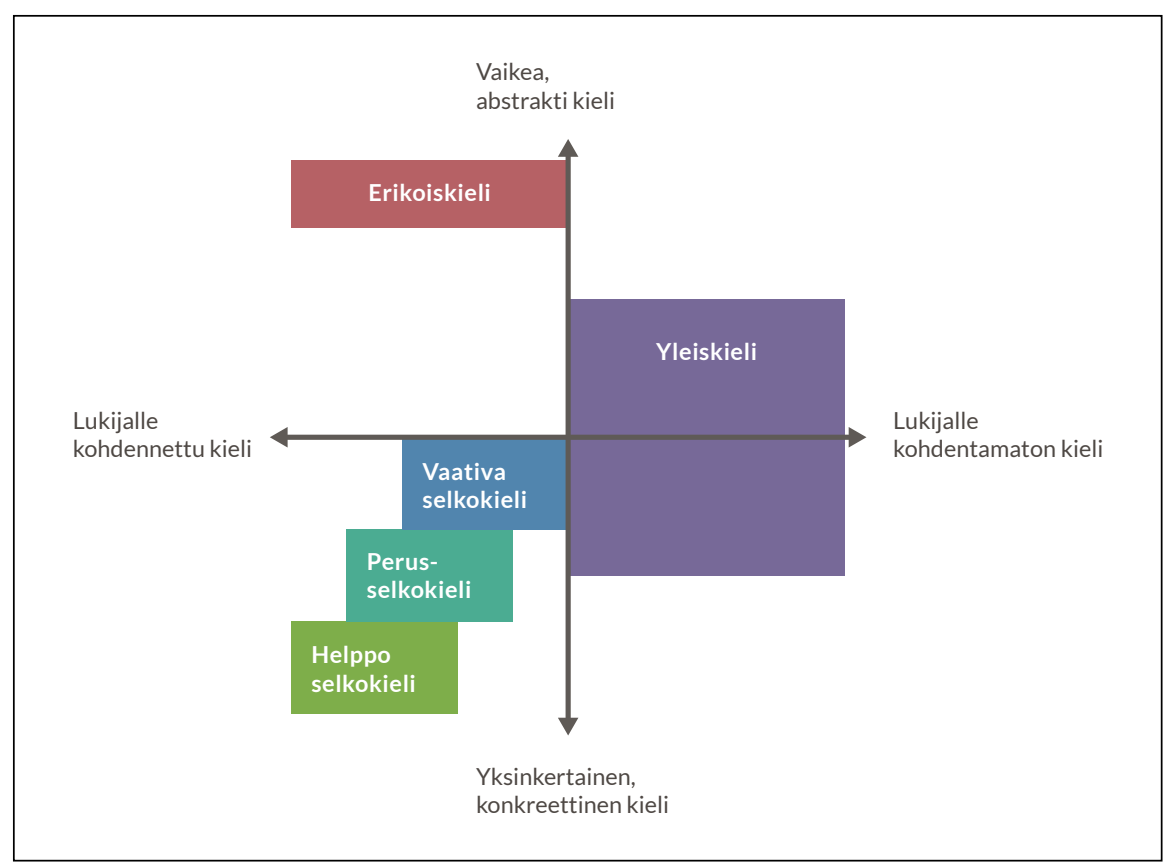

Vastaanottajan kielellisen osaamisen huomioon ottaminen mainitaan myös selkokielen määritelmässä (ks. esim. Leskelä, 2019 , s. 95; Virtanen, 2009, s. 17). Tässä mielessä selkokieli muistuttaa erikoiskielen muotoja kuten vaikkapa tieteen kieltä, joka on samaan tapaan suunnattu rajatulle joukolle vastaanottajia. Yleiskielessä sen sijaan vastaanottajalle muotoilu ei ole yhtä keskeistä kuin selkokielessä, vaikka yleensä tekstit pyritäänkin kirjoittamaan jollekin lukijakunnalle (Virtanen, 2009, s. 11). Yleiskielen on nimensä mukaisesti tarkoitus tavoittaa suuri, tarkemmin määrittelemätön joukko keskimääräisiä kielenkäyttäjiä, joita yhdistää lähinnä se, että heillä ei ole erityisiä kielellisiä vaikeuksia (Kulkki-Nieminen, 2002; Leskelä, 2019, s. 94-95).
Selkokieli eroaa yleiskielestä etenkin lukijalle kohdentuvuuden suhteen, erikoiskielestä taas kielen vaikeustason osalta. Tästä syystä selkokielen mittariin lisättiin myös yksi kriteeri liittyen kohderyhmille kohdentamiseen.

\subsubsection{Lukijalle mielekkäät sisällöt}

Toinen selkokieltä ja yleiskieltä erottavat tekijä liittyy siihen, että selkotekstin sisältöjen tulisi olla lukijan kannalta mielekkäitä (vrt. Virtanen, 2009, s. 70-72, vrt. myös Sainio, 2006). Kun asiantuntijoita pyydettiin arvioimaan, mitkä mittarin kriteerit erottavat selkotekstin yleiskielisestä, useimmat mainitsivat seuraavat: Tekstin aihe on sellainen, että sitä voi pitää kohderyhmälle mielekkäänä ( $\mathrm{k} 6$ ) ja 
Aihetta käsitellä̈n konkreettisella, havainnollisella tavalla, esimerkiksi kiinnittämällä asia aikaan ja paikkaan tai muuten konkretisoimalla (k8).

Selkotekstiä erottaa yleiskielestä siis se, että siinä on oltava lukijaa puhutteleva sisältö. Vaikka yleiskielessäkin yleisesti on tarkoitus kirjoittaa aiheista, jotka kiinnostavat lukijaa, se ei ole yhtä ratkaisevaa kuin selkokielessä. Yleiskielinen teksti on yleiskieltä, vaikka joku lukija ei pitäisi aihetta mielekkäänä. Selkotekstiä ei sen sijaan pidä kirjoittaa aiheesta, joka ei ole lukijalle mielekäs - vaikkapa kirja-arvostelua tieteellisestä teoksesta, jota ei ole selkokielellä saatavilla, tai pöytäkirjaa organisaation strategiapalaverista. Lukeminen on selkokieltä tarvitsevalle niin työlästä, että häntä ei pidä rasittaa tekstillä, joka ei ole hänelle mielekäs. Mielekkyys ei tarkoita sitä, että jokaisen selkotekstin on miellytettävä tai viihdytettävä häntä, vaan sitä, että teksti antaa hänelle jotakin olennaista.

\subsection{Selkokielen mittarin jatkokehittäminen}

Kaiken kaikkiaan selkokielen mittarin kehitystyö ja testaustulokset näyttävät, että mittaria voidaan käyttää selkokielen perustason arvioimisessa, mutta siinä on vielä puutteita ja tarkennettavaa. Mittari on toistaiseksi laajin ja täsmällisin kuvaus selkosuomen piirteistä, ja testauskierrosten jälkeen korjattuna se antaa riittävän luotettavan tuloksen perusselkokielen tasosta.

Mittarin puutteet liittyvät muun muassa siihen, miten se ottaa huomioon tekstin kohdentamisen juuri selkokieltä tarvitsevalle henkilölle sekä tekstin mielekkyyden ajatellulle lukijakunnalle. Mittaria on jatkossa kehitettävä myös selkokielen vaikeustasojen erottelemiseen. Sanaston osalta mahdollisia suuntaviivoja tähän voi tarjota esimerkiksi alkusanakielen teoria, etenkin helpon selkokie- len osalta (ks. esim. Goddard \& Wierzbicka, 2018; Vanhatalo \& Tissari, 2017; Leskelä \& Vanhatalo, tulossa; Vanhatalo \& Lindholm, 2020). Toisaalta vaativan tason kriteeristöä voisi peilata edistyneille kielenoppijoille (B2, C1-2) suunnatuissa oppimateriaaleissa käytettyyn sanastoon ja kielen rakenteisiin, vaikka kaikki vaativan selkokielen tason lukijat eivät olekaan kielenoppijoita.

Mittarin vaikeimmin ratkaistava ongelma on sen kyky erottaa selkokieli yleiskielestä. Erityisen hankalaa on osoittaa, missä kulkee vaativan selkokielen ja helpon yleiskielen raja, jos mittaria jatkossa kehitetään myös selkokielen eri vaikeustasojen arviointiin. Vaativa selkokieli voi joissakin tilanteissa olla kielellisesti jopa vaikeampaa kuin hyvin helppo yleiskieli. Vaikka aivan tarkkaa rajakohtaa kielimuotojen välille ei saisi määriteltyä, vertailevalla tekstintutkimuksella sekä selkokielen kohderyhmille suunnatuilla lukijatutkimuksilla voidaan kartoittaa harmaata aluetta yleiskielen ja selkokielen välillä.

\section{JOHTOPÄÄTÖKSET}

Selkokielen vaikeustasoille on Suomessa tarvetta, jotta selkotekstien tuottamisessa on mahdollista ottaa paremmin huomioon erilaiset kohderyhmät ja jotta eritasoisille lukijoille löytyisi kullekin soveltuvaa luettavaa. Tässä artikkelissa on kuvattu hahmotelma selkokielen vaikeustasojen määrittelemiseksi.

Hahmotelman lähtökohtana on perusselkokieli. Se on laajasti eri selkokielen kohderyhmille suunnattu yleisselkokielen taso, joka on tarkasti määritelty selkokielen mittarissa. Tämän tason selkotekstejä on tuotettu Suomessa vuosikymmenien ajan eniten, joten kokemusta ja materiaalia on runsaasti. Helppo selkokieli on perusselkokieltä helpompaa. Se pyritään kohdentamaan lukijalle, jolla on hyvin vähäiset kielelliset taidot ja joka tarvitsee paljon tukea luetun ymmärtämiseen. Vaativa 
selkokieli puolestaan on kielellisesti perusselkokieltä kompleksisempaa. Vaativan tason selkotekstistä voivat hyötyä henkilöt, joiden lukemisen ongelmat ovat lievempiä. Tällä tasolla selkokielen periaatteet ovat joustavia ja sisältävät jo osin yleiskielen elementtejä, mutta helpoissa lause- ja tekstikonteksteissa. Vaikeustasoista muodostuu näin polku, jota kielellistä tukea tarvitseva henkilö voi siirtyä tasolta toiselle kohti aina vaativampia tekstejä ja yleiskieltä, jos hänellä on edellytyksiä siihen.

Tasojen karkeat suuntaviivat ovat olemassa ja perusteltavissa käytännön selkotekstien pohjalta, mutta niiden tarkemmat kielelliset määrittelyt vaativat vielä kehittämistä. Erityisesti helpon ja perusselkokielen morfosyntaktista määrittelyä on tarkennettava. Vaativa selkokieli kokonaisuudessaan on vielä melko tarkentumaton, joskin sen kohdalla tavoitteena onkin kehittää joustavat ja moneen sovellettavissa olevat periaatteet tarkkojen sääntöjen sijaan. Tärkeää on myös saada tutkimusta ja käyttäjätestausta helpon ja vaativan selkokielen soveltamisesta erilaisilla lukijoilla.

Perusselkokielen arvioimiseen on kehitetty selkokielen mittaria, jonka kehitystyötä on kuvattu tässä artikkelissa. Mittari sisältää toistaiseksi tarkimman ja laajimman kriteeristön, joka selkosuomesta tällä hetkellä on olemassa. Aikaisemmat selkokielen ohjeistukset eivät ole yksilöineet näin tarkasti selkoteksteissä esiintyviä ja selkokielen asiantuntijoiden hyväksymiä selkokielen piirteitä eivätkä suhteuttaneet niitä toisiinsa.

Tämän artikkelin tarkastelun perusteella mittaria voidaan hyödyntää selkotekstien perustason arvioinnissa, mutta sitä ei voi pitää vielä täysin valmiina. Koska mittaria on kehitetty lähinnä käytännön selkokielistämisen tarpeisiin, sen tieteelliseen validoimiseen tarvitaan lisää tutkimusta, uusia testauskierroksia sekä laajoja kohderyhmien lukijatestauksia. Mittarin osakriteerien ryhmittely ja säätö vaativat vielä kehittämistä, etenkin niiden kriteerien osalta, jotka koskevat tekstin kohdentamista kielellistä tukea tarvitsevalle henkilölle sekä tekstin mielekkyyttä ajatellulle lukijakunnalle. Erityistä huomiota mittarin jatkokehittämisessä tulee kiinnittää siihen, miten mittarilla saadaan riittävän yksiselitteisesti esille selkokielen ja yleiskielen ero.

Selkokielen mittariin on koottu vuosikymmenten aikana kertynyt tieto selkokielen piirteistä. Se on yksi askel eteenpäin pyrkimyksessä määritellä tarkemmin selkokielen periaatteet ja nostaa yksityiskohtaiseen tarkasteluun kaikki se, mikä tekee tekstistä selkokieltä tarvitsevalle lukijalle helppoa tai vaikeaa. Samalla mittari antaa selkokielen periaatteille muodon, jota voidaan tarkastella kriittisesti tutkimuksen näkökulmista. Selkokielen kehittämiselle on ratkaisevan tärkeää, että tulevat selko-ohjeistukset ja selkokieliset tekstit pohjautuvat entistä enemmän tutkimustuloksiin. 


\section{LÄHTEET}

Bock, B. M. (2015). Anschluss ermöglichen und die Vermittlungsaufgabe ernst nehmen. Didaktik Deutsch, 38, 9-17.

Bock, B. M. \& Lange, D. (2015). Was ist eigentlich "Leichte Sprache"? Der Blick der Sprachwissenschaft. Teoksessa K. Candussi \& W. Fröhlich (toim.), Leicht Lesen. Der Schlüssel zur Welt (s. 63-79). Wien: Böhlau Verlag.

Bock, B. M., Fix, U. \& Lange, D. (2017). Das Phänomen "Leichte Sprache" im Spiegel aktueller Forschung. Teoksessa B. M. Bock, U. Fix \& D. Lange (toim.), "Leichte Sprache" im Spiegel theoretischer und angewandter Forschung, (s. 11-31). Berlin: Frank \& Timme.

Bock, B. M. (2019). "Leichte Sprache”. Kein Regelwerk. Sprachwissenschaftliche Ergebnisse und Praxisempfehlungen aus dem LeiSA-Projekt. Bundesministerium für Arbeit und Soziales / Universität Leipzig. Berlin: Frank \& Timme.

Bredel, U. \& Maaß, C. (2016a). Leichte Sprache. Theoretische Grundlagen, Orientierung für die Praxis. Berlin: Dudenverlag.

Bredel, U. \& Maaß, C. (2016b). Ratgeber Leichte Sprache. Die wichtigsten Regeln und Empfehlungen für die Praxis. Berlin: Dudenverlag.

Bredel, U. \& Maaß, C. (2017). Wortverstehen durch Wortgliederung. Bindestrich und Mediopunkt in Leichter Sprache. Teoksessa B. M. Bock, U. Fix \& D. Lange (toim.), "Leichte Sprache" im Spiegel theoretischer und angewandter Forschung, (s. 211-228). Berlin: Frank \& Timme.

Bredel, U. \& Maaß, C. (2019). Leichte Sprache. Teoksessa C. Maaß \& I. Rink (toim.), Handbuch Barrierefreie Kommunikation (s. 251272). Berlin: Frank \& Timme.

BITV 2.0 -asetus (2011). Verordnung zur Schaffung barrierefreier Informationstechnik nach dem Behindertengleichstellungsgesetz (Barrierefreie-Informationstechnik-Verordnung - BITV 2.0). https://www.gesetze-iminternet.de/bitv_2_0/BJNR184300011.html (2.3.2019)

Candussi, K. \& Fröhlich, W. (2015). Informationsbarrieren und Wege zu ihrer Überwindung. Das Konzept Barrierefreie Information, seine Herleitung und seine Funtionen. Teoksessa K. Candussi \& W. Fröhlich (toim.), Leicht Lesen. Der Schlüssel zur Welt (s. 9-38). Wien: Böhlau Verlag.
Christmann, U. (2017). Wie leicht darf Leichte Sprache sein? Empirische Lücken in einem gut gemeinten Konzept. Teoksessa B.M. Bock, U. Fix \& D. Lange (toim.), "Leichte Sprache" im Spiegel theoretischer und angewandter Forschung (s. 35-51). Berlin: Frank \& Timme.

Ehri, L. \& McCormick, S. (1998). Phases of word learning: Implications for instruction with delayed and disabled readers. Reading and Writing Quarterly, 14, 135-163.

Fröhlich, W. (2017). Von der "Leichten Sprache" zur zielgruppengerechten Information: Leicht Lesen in Österreich. Teoksessa B. M. Bock, U. Fix \& D. Lange (toim.), "Leichte Sprache" im Spiegel theoretischer und angewandter Forschung (s. 415-430). Berlin: Frank \& Timme.

Goddard, C. \& Wierzbicka, A. (2018). Minimal English and how it can add to Global English. Teoksessa C. Goddard (toim.), Minimal English for a Global World. Improved communications using fewer words, (s. 5-28). Brisbane: Palgrave MacMillan.

Gross, S. (2015). Regeln und Standards für leicht verständliche Sprache. Teoksessa K. Candussi \& W. Fröhlich (toim.), Leicht Lesen. Der Schlüssel zur Welt (s. 81-106). Wien: Böhlau Verlag.

Hallik, S. \& Janssen, A. (2017). Das Projekt "Parlamentdeutsch in Einfacher Sprache”. Teoksessa B. M. Bock, U. Fix \& D. Lange (toim.), "Leichte Sprache" im Spiegel theoretischer und angewandter Forschung (s. 373-386). Berlin: Frank \& Timme.

Heikkinen, V. (2012). Ymmärrettävyystutkimuksen kysymyksiä. Kielikuvia, 2, 2012.

IE (2009). Make your information accessible! European standards to make information easy to read and to understand.http://easy-to-read. eu/wp-content/uploads/2014/12/EN Information for_all.pdf (19.8.2018)

IFLA (1996). Easy-to-Read - An important part in reading promotion and in the fight against illiteracy. Bror Tronbacken seminaariluento. http://www.facillectura.es/documentos/recursos/EasyRead.pdf (19.8.2018)

IFLA (2010). International Federation of Library Association and Institutions IFLA Professional Reports, No. 120. https://www.ifla. org/files/assets/hq/publications/professionalreport/120.pdf (19.8.2018) 
ILSHM (1998). Tee se helpoksi. Eurooppalainen opas selkokielisen informaation tuottamiseksi kehitysvammaisille ihmisille. http://jkorpela. fi/helpoksi.html (19.8.2018)

Juusola, M. (2016). Selkosanomien lukijakysely 2016. https://selkokeskus.fi/wordpress/wpcontent/uploads/2017/08/Selkosanomien lukijakysely 2016.pdf (19.8.2018)

Kartio, J. (2009). Miten puhua selkokieltä? Teoksessa J. Kartio (toim.), Selkokieli ja vuorovaikutus (s. 8-23). Helsinki: Kehitysvammaliitto / Opike.

Kulkki-Nieminen, A. (2002). Selkokielen ja yleiskielen eroista. Teoksessa H. Virtanen (toim.), Selko-opas (s. 33-46). Tampere: Kehitysvammaliitto.

Kulkki-Nieminen, A. (2010). Selkoistettu uutinen. Lingvistinen analyysi selkotekstin erityispiirteis$t a ̈$. Tampere: Tampere University Press.

Kulkki-Nieminen, A. \& Leskelä, L. (2012). Selkoistaminen ja tekstilajit. Teoksessa V.

Heikkinen, E. Voutilainen, P. Lauerma, U. Tiililä \& M. Lounela (toim.), Genreanalyysi tekstilajitutkimuksen käytäntöä (s. 545-574). Kotimaisten kielten keskuksen verkkojulkaisuja 29. Helsinki: Kotimaisten kielten keskus (4.3.2019).

Lang, K. (2019). Die rechtliche Lage zu Barrierefreie Kommunikation in Deutschland. Teoksessa C. Maaß \& I. Rink (toim.), Handbuch Barrierefreie Kommunikation (s. 67-93). Berlin: Frank \& Timme.

Leskelä, L. (2019). Selkokieli. Saavutettavan kielen opas. Helsinki: Opike.

Leskelä, L. (2017). Textgenre-orientierte Prinzipien für Leichtes Finnisch. Teoksessa B. M. Bock, U. Fix \& D. Lange (toim.), "Leichte Sprache" im Spiegel theoretischer und angewandter Forschung (s. 431-446). Berlin: Frank \& Timme.

Leskelä, L. (2015). Von Selko zu Leicht Lesen. Ein nordischer Blick auf die praktische Durchsetzung eines Bürgerrechtes. Teoksessa K. Candussi \& W. Fröhlich (toim.), Leicht Lesen. Der Schlüssel zur Welt (s. 169-185). Wien: Böhlau Verlag.

Leskelä, L. (2012). Selkokielisen vuorovaikutuksen ohjeet. Teoksessa L. Leskelä \& C. Lindholm (toim.), Haavoittuva keskustelu: Keskustelunanalyyttisiä tutkimuksia kielellisesti epäsymmetrisestä vuorovaikutuksesta (s. 279-298). Helsinki: Kehitysvammaliitto ry.
Leskelä, L. (2011). Selkotekstin testaus. Raportti. https://selkokeskus.fi/wordpress/wp-content/ uploads/2016/09/Selkotekstin_testaus_2011. pdf. (19.5.2019)

Leskelä, L. \& Kulkki-Nieminen, A. (2015). Selkokirjoittajan tekstilajit. Helsinki: Opike.

Leskelä, L. \& Lindholm, C. (2012). Lukijalle. Teoksessa L. Leskelä \& C. Lindholm (toim.), Haavoittuva keskustelu. Keskustelunanalyyttisia tutkimuksia kielellisesti epäsymmetrisestä vuorovaikutuksesta. Kehitysvammaliiton tutkimuksia 6. Helsinki: Kehitysvammaliitto.

Leskelä, L. \& Virtanen, H. (2006). Selkokielen ABC. Teoksessa L. Leskelä \& H. Virtanen (toim.) Toisin sanoen. Selkokielen teoriaa ja käytäntöä (s. 7-14). Helsinki: Opike.

Leskelä, L. \& Vanhatalo, U. (tulossa). Minimal languages meet easy-to-read. Hunt for the simplest possible vocabulary. Alkusanakieltä koskevassa teoksessa, C. Goddard (toim.).

Maaß, C. (2015). Leichte Sprache. Das Regelbuch. Forschungsstelle Leichte Sprache. Berlin: LIT Verlag.

Maaß, C. \& Rink, I. (2019). Über das Handbuch Barrierefreie Kommunikation. Teoksessa C. Maaß \& I. Rink (toim.), Handbuch Barrierefreie Kommunikation (s. 17-25). Berlin: Frank \& Timme.

NLS (2013). Die Regeln für Leichte Sprache.

http://www.leichte-sprache.de/dokumente/ upload $/ 21 \mathrm{dba}$ regeln fuer leichte sprache. pdf. (1.8.2019)

Nummelin, T., Matikka, L. \& Vesala, H. (2000). Kohteesta kumppaniksi. Kehitysvammaiset Elämänkulkututkimuksen haastattelijoina. Helsinki: Kehitysvammaliitto.

Numminen, H. (2006). Muisti ja lukeminen. Teoksessa L. Leskelä \& H. Virtanen (toim.), Toisin sanoen. Selkokielen teoriaa ja käytäntöä (s. 32-36). Helsinki: Opike.

Sainio, A. (2006). Oikeus kelpo tarinoihin. Teoksessa L. Leskelä \& H. Virtanen (toim.), Toisin sanoen. Selkokielen teoriaa ja käytäntöä (s. 131154). Helsinki: Opike.

Sainio, A. (2014). Säpinät. Seitsemän pientä kirjaa Manusta ja Sannasta. Helsinki: Opike.

Sainio, A. \& Rajala, P. (2002). Ohjeita selkokirjoittajille. Teoksessa Virtanen, H. (toim.), Selkoopas (s. 23-32). Helsinki: Opike. 
Schädler, J. \& Reichstein M. F. (2015). "Leichte Sprache und Inklusion. Teoksessa K. Candussi \& W. Fröhlich (toim.), Leicht Lesen. Der Schlüssel zur Welt (s. 39-61). Wien: Böhlau Verlag.

THL (2018). Matkailijan terveysopas. https:// www.terveyskirjasto.fi/terveyskirjasto/ktl. mat?p selaus $=2317$ (12.2.2019)

Uotila, E. (2012). Selkokieltä esitteillä. Kelan selkokielisten ja yleiskielisten esitteiden tekstuaalinen analyysi. Pro Gradu -tutkielma. Helsinki: Helsingin yliopisto.

Uotila, E. (2019). Selko Suomessa - Selkokielen kehitys ja sovelluksia. Puhe ja kieli, 39, 307-324.

Vanhatalo, U. \& Tissari, H. (2017). Esittelyssä alkusanakieli. Virittäjä, 121, 244-263.

Vanhatalo, U. \& Lindholm, C. (2020). Prevalence of NSM primes in Easy-to-Read and Standard Finnish: Findings from newspaper text corpora. Teoksessa L. Sadow, Lauren, B. Peeters, Bert \& K. Mullan (toim.), Studies in ethnopragmatics, cultural semantics, and intercultural communication. Vol. 3. Minimal English (and Beyond) (s. 213-234). Springer.

Virtaluoto, J. \& Väyrynen, P. (2000). Voidaanko tekstin luettavuutta mitata matemaattisilla indekseillä? Informaatiotutkimus, 19, 100-106.

Virtanen, H. (2009). Selkokielen käsikirja. Helsinki: Opike.

Wiio, O.A. (1974): Ymmärretäänkö sanomasi? Viestintä - tiedonvälitys. Helsinki: Weilin \& Göös.

Zurstrassen, B. (2017). Leichte Sprache - eine Sprache der Chancengleichheit? Teoksessa B. M. Bock, U. Fix \& D. Lange (toim.), "Leichte Sprache" im Spiegel theoretischer und angewandter Forschung (s. 53-69). Berlin: Frank \& Timme.

\section{VERKKOLÄHTEET}

boksok.no:

https://boksok.no/ (12.2.2019)

finlex.fi:

https://www.finlex.fi/fi/esitykset/

he/2018/20180060 (2.4.2019)

lix:

http://www.readabilityformulas.com/theLIX-readability-formula.php (8.8.2018)

llforlaget.se:

http://ll-forlaget.se/hem/

nivaer ?levelId $=540 \&$ letter $=1$ (12.2.2019)

nyponforlag.se:

https://www.nyponforlag.se/bocker-pasvenska/; (12.2.2019)

readabilityformulas:

www.readabilityformulas.com $(8.8 .2018)$

Selkokielen mittari:

https://selkokeskus.fi/selkokieli/selkokielen-

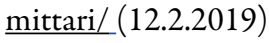

selkosanomat/kuva:

https://selkosanomat.fi/kuva/ (15.8.2019)

selkouutiset/tosihelppo:

https://yle.fi/uutiset/osasto/selkouutiset/ tosi helppo/ (15.8.2018)

YK-liitto:

https://www.ykliitto.fi/sites/ykliitto.fi/ files/vammaisten_oikeudet_2016_net.pdf (19.8.2018)

leichte-sprache.org: https://www.leichte-sprache.org/die-regeln/ (12.2.2019) 


\section{THE DIFFICULTY LEVELS OF EASY FINNISH - EVALUATING TEXTS USING THE FINNISH EASY LANGUAGE METER}

Leealaura Leskelä, The Finnish Association on Intellectual and Developmental Disabilities / Finnish Centre for Easy Language

The need for easy language has increased in recent years. A need has simultaneously emerged to more precisely define the difficulty level of Easy Finnish and how it differs from other language forms. How easy or difficult is it for different readers and in different texts? And is it possible to evaluate whether or not a text is in Easy Finnish? This article reflects on the ways in which the difficulty levels of Easy Finnish could be defined. Easy language materials have always been produced at many levels in Finland, but these levels have never been defined. Thus, the users of the materials have been unsure whether or not certain materials are suitable for them. In practice, materials are needed at many difficulty levels, as some users have severe linguistic problems and reading barriers whereas others have only minor disadvantages. This article outlines preliminary criteria for three difficulty levels: Simple, Basic and Advanced Easy Finnish. As the need for Easy Finnish continues to grow, experts and researchers need more evaluation instruments. The Finnish Centre for Easy Language has recently developed The Finnish Easy Language Meter, which aims to evaluate whether or not the level of a text is Basic Easy Finnish. The Meter is, so far, the most accurate collection of textual, lexical and structural criteria of Easy Finnish texts. However, is it a reliable instrument for evaluating an easy text? This article discusses this issue in the light of the Meter's testing process experiences and iteration results.

Keywords: difficulty levels of Easy Finnish; Easy Finnish; Easy-to-Read; EtR-Meter; Evaluation of Easy-to-Read 


\section{LIITE: \\ TIIVISTELMÄ SELKOKIELEN MITTARIN KIELEEN LIITTYVISTÄ KRITEEREISTÄ}

\section{TEKSTI KOKONAISUUTENA}

Yleiskriteerit: 1. Teksti noudattaa suomen oikeinkirjoitussuosituksia. 2. Tekstissä ei ole asiavirheitä. 3. Tekstin sisältö vastaa otsikkoa. 4. Tekstin ajateltu lukija on selkokieltä tarvitseva henkilö. 5. Teksti on kokonaisuutena arvioituna yleiskieltä helpompaa.

Aiheen valinta ja sen käsittely: 6. Tekstin aihe on sellainen, että sitä voi pitää kohderyhmälle mielekkäänä. 7. Aihetta käsitellään lukijan kannalta mielekkäästä näkökulmasta. 8. Aihetta käsitellään konkreettisella, havainnollisella tavalla. 9. Jos aihe on abstrakti, siitä on annettu konkreettisia esimerkkejä. 10. Aihetta käsitellään pääosin konkreettisten toimijoiden, olentojen, esineiden tms. kautta. 11. Toimijoina on vain vähän abstrakteja substantiiveja, kuten esimerkiksi käsitteitä tai tekstejä.

Informaation määrä: 12. Tekstissä on sopiva määrä informaatiota (ei liikaa). 13. Tekstistä ei puutu olennaista informaatiota. 14. Tekstissä on ennakoitu, millaista tietoa ja kuinka paljon lukija tarvitsee aiheesta. 15. Teksti ei ole liian tiivistä, yhteen lauseeseen ei ole tiivistetty liikaa asiaa.

Tekstin sävy ja vuorovaikutus lukijan kanssa: 16. Tekstin sävy on sen tavoitteiden kannalta sopiva. 17. Tekstin sävy ilmaisee, että kirjoittaja suhtautuu lukijaan arvostavasti. 18. Tekstin sävy ei ole liian opettavainen eikä lukijaa aliarvioiva. 19. Tekstin sävy ottaa huomioon lukijan iän (lapsi, nuori, aikuinen, vanhus).

Tekstin jäsentely: 20. Teksti etenee johdonmukaisesti. 21. Teksti on jaettu sopivankokoisiin kokonaisuuksiin. 22. Teksti on jaettu pituudeltaan sopivankokoisiin kappaleisiin. 23. Kappaleet liittyvät toisiinsa luontevalla tavalla, tekstinsisäinen sidosteisuus on hyvä. Lukija pystyy vaivatta havaitsemaan tekstin syy-seuraussuhteet, ajallisesti peräkkäiset asiat, ehdollisesti toisistaan riippuvaiset asiat. 24. Tekstin rakenne auttaa kiinnittämään huomiota olennaiseen. 25. Tekstin pääviestin kannalta olennaisin informaatio on tekstin alussa. 26. Tekstissä ei ole sisällöllisiä aukkoja (lukija saa joka kohdassa tekstin ymmärtämisen kannalta riittävän informaation). 27. Tekstissä ei ole epäselviä intertekstuaalisia viitteitä (teksti selittää itse itsensä eikä nojaa liikaa lukijan maailmantietoon tai muiden tekstien tuntemukseen). 28. Tekstissä ei ole luetun ymmärtämistä rasittavia viittauksia toisiin kohtiin tekstiä. 29. Aikamuotojen käyttö tekstissä on johdonmukaista eikä eri aikamuotoja ole liikaa; lukijan on helppo hahmottaa tekstin aikatasot.

Tekstilajikriteerit: 30 . Teksti noudattaa edustamansa tekstilajin kriteerejä (informoivat tekstit, kaunokirjalliset tekstit, mediatekstit).31. Otsikko auttaa hahmottamaan, mistä tekstilajista on kyse. 32. Tekstilajipiirteitä on korostettu siten, että lukijan ei tarvitse arvailla tekstilajia.

\section{SANAT}

Yleiskriteerit: 33. Käytetään yleistä ja kohderyhmälle tutuksi arvioitua sanastoa. 34 . Suositaan lyhyitä sanoja. 35. Vältetään, jos niille yleinen kotoperäinen vastine. 36 . Suositaan konkreettisia sanoja; jos tekstissä on näennäisesti konkreettisia sanoja, jotka todellisuudessa tarkoittavat abstrakteja asioita, ne selitetään.

Sanojen selittäminen: 37 . Selitetään ymmärrettävällä tavalla sanat, jotka voidaan olettaa kohderyhmälle vieraaksi. Selitys on siinä kohdassa, missä sanat esiintyvät ensimmäistä kertaa. 38. Tekstissä ei selitetä sanoja, jotka voidaan olettaa lukijalle tutuksi. 39. Sanat 
selitetään luontevalla tavalla, joka ei vaikuta osoittelevalta. 40. Tekstissä ei ole liikaa erikoiskielisiä sanoja; erikoiskielisistä käsitteistä on valittu olennaiset ja ne on selitetty hyvin. Sanojen toisto ja niihin viittaaminen: 41 . Toistoa käytetään siten, että se lisää tekstin ymmärrettävyyttä.42. Pitkissä yhdyssanoissa on hyödynnetty osittaistoistoa ensimaininnan jälkeen. 43. Synonyymien käyttö on johdonmukaista ja luontevaa. 44. Synonyymejä käytetään maltillisesti (samaan asiaan ei viitata liian monella eri tavalla).

Kuvallinen kieli: 45. Käytetään tuttuja ja yleisiä kielikuvia, joita on vaikea korvata muilla sanoilla. 46. Kielikuvia käytetään maltillisesti. 47. Tekstissä ei käytetä kielikuvia, joiden ymmärtäminen vaatii luovaa päättelyä.

Luvut ja lyhenteet: 48 . Tekstissä ei ole paljon isoja lukuja.49. Luvut, lukumäärät, mittayksiköt ja lukujen väliset suhteet on esitetty havainnollisella ja konkreettisella tavalla, lukuja on likimääräistetty.50. Tekstissä ei käytetä lyhenteitä (pois lukien vakiintuneet lyhenteet, esimerkiksi Kela).

\section{KIELEN RAKENTEET}

Yleiskriteerit: 51. Tekstissä käytetään helposti hahmottuvia ja yleisiä kielen rakenteita (esim. indikatiivia, persoonamuotoista verbiä). 52. Tekstissä ei käytetä rakenteita, joissa on useita erilaisia kielellisiä elementtejä kuten taivutuspäätteitä, johtimia, liitteitä.

Sanojen taivutus ja johtaminen: 53 . Tekstissä suositaan nominien perusmuotoja, jos se on lauseyhteydessä mahdollista ja luontevaa. 54. Tekstissä ei ole harvinaisia sijamuotoja kuten abessiivia, komitatiivia, instruktiivia. 55. Tekstin verbit ovat pääosin preesensissä ja imperfektissä; liittomuotoja vältetään.

56. Verbin moduksista käytetään enimmäkseen indikatiivia ja imperatiivin 2. persoonaa; 57. Konditionaalia on käytetty vain tavallisissa ehtolauseissa. 58. Tekstissä ei käytetä harvinaisia verbimoduksia, kuten potentiaalia, vanhahtavia 3. persoonan imperatiivimuotoja. 59. Tekstissä ei ole tarpeettomia kieltomuotoja eikä kaksoiskieltolauseita. 60 . Yhteen kuuluvat sanat, kuten verbiliitot ja verbien rektion mukaiset ilmaukset, esitetään peräkkäin tai mahdollisimman lähekkäin.61. Tekstissä ei käytetä vaikeita infinitiivi- ja partisiippirakenteita. 62. Pronominiviittaukset eivät jää epämääräisiksi tai liian kauas viittauskohteestaan. 63. Sanajohdoksissa suositaan yleisiä johdostyyppejä, joilla muodostetaan usein esiintyviä sanoja.

Lause- ja virkerakenteet: 64 . Tekstissä ei käytetä lauseenvastikkeita. 65. Tekstissä suositaan lauseita, jotka rakentuvat persoonamuotoisen verbin varaan. 66. Tekstissä ei ole ilmauksia, jotka ovat substantiivityylisiä (ns. substantiivitauti). 67. Tekstissä käytetään passiivia vain silloin, kun tekijä ei ole tiedossa tai on yhdentekevä. 68. Lauseet ovat lyhyitä, ja predikaatti sijaitsee pääosin lauseen alkupuolella. 69. Yhdessä lauseessa ilmaistaan vain yksi tärkeä asia. 70. Luetelmat ovat lyhyitä; luetelman johtolause on lausemuotoinen. 71. Virkkeet ovat pääosin lyhyitä. 72 . Virkerakenteet ovat yksinkertaisia; jos virkkeessä on enemmän kuin yksi sivulause, sen rakenne on laskeva. 73. Suositaan suoraa sanajärjestystä. Käänteistä sanajärjestystä käytetään vain silloin, jos lauseen tai virkkeen temaattinen rakenne niin vaatii tai teksti muuten muuttuu monotoniseksi. 74. Lauseessa ja virkkeessä ilmaistaan yleensä tuttu asia ensin ja uusi sen jälkeen. 75 . Tekstissä ei käytetä kiilalauseita. 76. Kahden lauseen virkkeissä päälauseella on pääosin vain yksi sivulause. 77. Tekstissä ei ole rinnasteisia sivulauseita samassa virkkeessä. 78. Lauseet ja virkkeet on sidottu toisiinsa tavalla, joka tekee kirjoittajan päättelyketjun näkyväksi. 79 . Virkkeessä on käytetty yleisiä suhteuttavia sanoja, jotka lisäävät sidosteisuutta.

80. Virkkeissä ei käytetä kaksoiskieltoja. 
